\title{
Crystallization, Structure and Functional Robustness of Isocitrate Dehydrogenases
}

\author{
Noriyuki Ishii \\ National Institute of Advanced Industrial Science and Technology (AIST) \\ Japan
}

\section{Introduction}

Understanding in detail the function of proteins and complexes requires knowledge of their three-dimensional structure. Historically, early development of protein crystallization, only provided a means for the purification of specific proteins from an impure mixture and an index that a protein had been purified (McPherson, 2004). X-ray diffraction analysis in combination with crystallization has become indispensable techniques for establishing the properties and nature of catalytic macromolecules. In spite of remarkable progress over the last two decades in the overexpression of macromolecules, in sophisticated screening of crystallization conditions, and X-ray data collection and analysis, the determination of novel structures by X-ray crystallography is still largely limited by the difficulty of obtaining highquality crystals of interest and maintaining their quality throughout the data collection stage.

The property of self-assembly exhibited by biological macromolecules plays a central role in biology. Most of the primary stage of the self-associated construction of supramolecular structures such as macromolecular complexes, assemblies, organelles, cell membranes, cytoskeletons, and so on, involves only the establishment of weak and oriented interactions between homologous molecules. The formation of protein crystals can be described as the expression of the self-assembly properties of the constituent molecules placed under favorable conditions. In order to engineer proteins that possess various kinds of physicochemical properties as well as biochemical functions within nano-assemblies, we need to understand features of the intermolecular interactions and the capacities for macromolecules to self-associate that govern the integrating of protein assemblies, such as seen in the primary stage of crystallization and crystal growth processes of protein molecules (Akiba et al., 2005; N. Ishii et al., 2001). It further requires information to specify how the building block molecules are joined into higher order structures. The fundamental and practical importance of these processes motivates the interest of studying self-assembly (self-organization). Crystals of a certain kind of protein belonging to different space groups may provide a better understanding of intermolecular interactions which can guide the development of techniques to manipulate the orientation of each protein molecule and arrangements in the construction of nano-architectures using the desired protein. The conformation of protein molecules as well as configurations of amino-acid residues are often stabilized in the supramolecular complex through the cumulative effects of various 
intermolecular interactions, such as salt bridges and hydrogen bonds, on the surface. Even in monomeric or dimeric proteins under physiological conditions sometimes seen as highly oligomeric complexes during crystal structure determination.

\section{Isocitrate dehydrogenase}

Isocitrate dehydrogenase (ICDH, EC 1.1.1.42) is a metal dependent $\left(\mathrm{Mg}^{2+}\right.$ or $\left.\mathrm{Mn}^{2+}\right)$ enzyme that plays an important role in the tricarboxylic acid cycle. It lies at a critical juncture between the cycle and the glyoxylate pathway to the biosynthesis of glutamate. The enzyme catalyzes the subsequent oxidative decarboxylation reaction of $2 \mathrm{R}, 3 \mathrm{~S}$-isocitrate to yield 2oxoglutarate and carbon dioxide with the protonation of NAD or NADP in the cycle. The 2oxoglutarate is known to be a key substrate in the biosyntheses of cell constituents via reductive amination to glutamate. These pathways are among the first to have evolved in the history of life (Melendez-Hevia et al., 1996). The ICDHs have been distinguished into three subfamilies based on sequence comparisons (Steen et al., 1997, 2001). All of the archaeal and most of the bacterial ICDHs are classified together into subfamily I, eukaryotic homodimeric ICDHs and some bacterial ICDHs are categorized as subfamily II, eukaryotic hetero oligomeric ICDHs constitute subfamily III. In contrast to these homologous proteins, another type of $\mathrm{NADP}^{+}$-dependent monomeric ICDHs with molecular mass of 80-100 kDa have been found (Chen \& Gadal, 1990). The active site of these enzymes in this category must be constructed from the side chains of residues within a single polypeptide chain. Although the monomeric ICDH catalyzes a reaction identical to that of the dimeric ICDH, no homology in the primary sequence has been found between the monomeric and dimeric ICDHs (Sahara et al., 2002). In addition, immunological studies suggest that monomeric and dimeric ICDHs are not structurally homologous (Fukunaga et al., 1992; Leyland \& Kelly, 1991). A certain bacterium such as Calwellia maris possesses both monomeric and dimeric ICDHs (Yoneta et al., 2004). It seems that transcription of both genes is regulated in response to environmental factors.

\section{Crystallization and study with the X-ray method}

For comprehensive understanding of the dynamics within the cell and the mechanisms responsible for the dynamics, we need to draw how the constituting molecules respond to chemical and physical forces, how the responses are regulated, and how the responses are transmitted through the hierarchy of assemblies and higher order structures. Although there have been techniques which reveal protein structures such as nuclear magnetic resonance (NMR), and cryogenic transmission electron microscopy (cryo-TEM) in combination with computer tomography methods, the dynamical properties discussed above require a level of atomic resolution which can only be addressed by X-ray crystallography.

The search stage for discovering appropriate crystallization condition for the macromolecules of interest is still difficult and time consuming. Figure 1 shows a conceptual diagram that shows such a crystallization condition search stage (screening on the landscape of potential free energy). Various parameters are derived from certain starting conditions, and the condition under which crystals suitable for X-ray crystallography are formed is sought by trial and error so as not to fall into local minima. In the parameters, there are many factors effecting crystallization such as temperature, gravity, magnetic field, $\mathrm{pH}$, precipitant type and concentration, ionic strength, reductive or oxidative environment, 
concentration of the sample protein, ligands, inhibitors, genetic or chemical modifications, and so on.

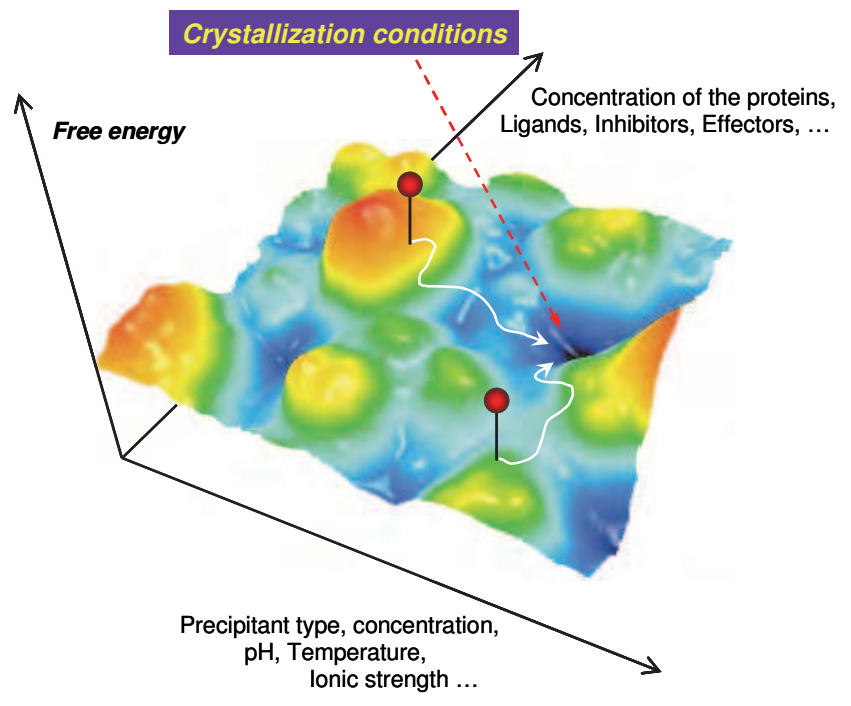

Fig. 1. Conceptual diagram of crystallization condition search screening on the landscape of potential free energy. Various parameters are shaken from certain starting conditions.

In our crystallization study of ICDH from a thermophile, Thermus thermophilus HB8 (Tth ICDH), Tth ICDH was overexpressed in E. coli MV1190 which carried plasmids pKID1, and the gene product was purified according to reported methods (Miyazaki et al., 1994). Purity of the yielded protein was checked with the polyacrylamide gel electrophoresis in the presence of sodium dodecyl sulfate (SDS-PAGE) (Laemmli, 1970). After dialysis against pure water, the protein was stored at $277 \mathrm{~K}$ until use. The crystallization experiments were carried out by the hanging drop vapor diffusion method in a 24-well tissue-culture linbro plate (Iwaki Glass Co., Ltd., Ciba, Japan) at 298 and/or 277 K. A random-screening protocol with screens developed in-house was used. The initial hits were optimized with further finer grid search. One screen package is similar to the Hampton Crystal Screen and Crystal Screen II (Hampton Research, Aliso Viejo, CA), and the other screen package contains various additives such as cofactors, inhibitors, nucleotides, minerals, salts and buffers with $\mathrm{pH}$ range 4 - 9. Tth $\mathrm{ICDH}$ was dialyzed against $20 \mathrm{mM}$ Tris- $\mathrm{HCl}, \mathrm{pH} 7.2$, at $277 \mathrm{~K}$, and incubated at $333 \mathrm{~K}$ for $10 \mathrm{~min}$ before the crystallization experiments. The initial protein solution contained $10.2 \mathrm{mg} / \mathrm{ml}$ of Tth ICDH in $20 \mathrm{mM}$ Tris-HCl, $\mathrm{pH}$ 7.2. To a droplet of the protein solution, an equal amount of reservoir solution was added and then the droplet was equilibrated over $0.5 \mathrm{ml}$ reservoir solution. The resulting microcrystals were obtained at the conditions with the reservoir commonly containing $100 \mathrm{mM}$ sodium cacodylate and $1.4 \mathrm{M}$ sodium acetate. The crystallization conditions were further optimized with regards to $\mathrm{pH}$, co-existence of DL-isocitric acid, citric acid and/or cations like $\mathrm{Mg}^{2+}$ and $\mathrm{Mn}^{2+}$. During the survey for crystallization conditions, information on protein crystallization such as 


\begin{tabular}{|c|c|c|c|c|c|c|c|c|}
\hline \multirow[b]{2}{*}{ Species } & \multirow{2}{*}{$\begin{array}{l}\text { Mol. } \\
\text { mass } \\
(\mathrm{kDa})\end{array}$} & \multirow{2}{*}{$\begin{array}{l}\text { 3D } \\
\text { structure }\end{array}$} & \multicolumn{3}{|c|}{ Crystallization condition } & \multirow{2}{*}{$\begin{array}{l}\text { Space } \\
\text { group }\end{array}$} & \multirow{2}{*}{$\begin{array}{l}\text { Unit cell } \\
\text { dimen- } \\
\text { sion }(\AA)\end{array}$} & \multirow[b]{2}{*}{ Reference } \\
\hline & & & Method & $\begin{array}{l}\text { Protein } \\
\text { solution }\end{array}$ & Precipitant & & & \\
\hline \multicolumn{9}{|c|}{ Subfamily I } \\
\hline \multicolumn{2}{|c|}{$\begin{array}{l}\text { Acidithiobacillus } \\
\text { thiooxidans }\end{array}$} & $\begin{array}{l}\text { available } \\
\text { at } 1.9 \AA\end{array}$ & hdvd & $\begin{array}{l}25 \mathrm{mM} \\
\mathrm{NAD}^{+}\end{array}$ & $\begin{array}{l}0.95-1.05 \mathrm{M} \mathrm{Na} \\
\text { citrate, } \mathrm{pH}: 4.6 \\
10 \% \text { Glycerol }\end{array}$ & $P_{4}{ }_{3}{ }_{1} 2$ & $\begin{array}{l}a=b=126 \\
c=268\end{array}$ & $\begin{array}{l}\text { Imada et al. } \\
\text { (2007) }\end{array}$ \\
\hline \multicolumn{2}{|c|}{ Aeropyrum pernix } & $\begin{array}{l}\text { available } \\
\text { at } 2.20 \AA\end{array}$ & & & $\begin{array}{l}\text { 12\% PEG6000 } \\
60 \mathrm{mM} \mathrm{MgCl}_{2} \\
100 \mathrm{mM} \mathrm{Na}^{-} \\
\text {citrate, } \mathrm{pH}: 5.6\end{array}$ & $P 4{ }_{3} 212$ & $\begin{array}{l}\mathrm{a}=\mathrm{b}= \\
107.6 \\
\mathrm{c}=171.1 \\
\alpha=\beta=\gamma= \\
90^{\circ}\end{array}$ & $\begin{array}{l}\text { Karlström } \\
\text { et al. }(2002, \\
2005)\end{array}$ \\
\hline & 47.9 & $\begin{array}{l}\text { available } \\
\text { at } 2.28 \AA\end{array}$ & sdvd & $\begin{array}{l}\text { 5mM Tris- } \\
\mathrm{HCl}, \mathrm{pH}: 8.0\end{array}$ & $\begin{array}{l}20 \% \text { PEG3350 } \\
200 \mathrm{mM} \\
\text { Diammonium } \\
\text { citrate, pH:5.0 }\end{array}$ & $P 43212$ & $\begin{array}{l}\mathrm{a}=\mathrm{b}= \\
107.9 \\
\mathrm{c}=172.9 \\
\alpha=\beta=\gamma= \\
90^{\circ}\end{array}$ & $\begin{array}{l}\text { Jeong et al. } \\
\text { (2004) }\end{array}$ \\
\hline $\begin{array}{l}\text { Archaegl } \\
\text { flugidus }\end{array}$ & & $\begin{array}{l}\text { available } \\
\text { at } 2.5 \AA\end{array}$ & hdvd & & $\begin{array}{l}0.6 \mathrm{M} \mathrm{ZnSO}_{4} \\
100 \mathrm{mM} \mathrm{Na}^{-} \\
\text {cacodylate }\end{array}$ & $P 22_{1}$ & $\begin{array}{l}\mathrm{a}=81.6 \\
\mathrm{~b}=65.4 \\
\mathrm{c}=87.2 \\
\beta=95.3^{\circ}\end{array}$ & $\begin{array}{l}\text { Stokke et } \\
\text { al. } \\
(2007)\end{array}$ \\
\hline \multicolumn{2}{|c|}{ Bacillus subtilis } & $\begin{array}{l}\text { available } \\
\text { at } 1.55 \AA\end{array}$ & hdvd & $\begin{array}{l}\text { 20mM } \\
\text { Tris-HCl, } \\
\text { pH:7.4 } \\
1 \mathrm{mM} \text { Citrate } \\
5 \mathrm{mM} \\
\mathrm{MgCl}_{2}, 5 \mathrm{mM} \\
\text { 2-Mercapto- } \\
\text { ethanol } \\
0.5 \mathrm{mM} \\
\text { PMSF } \\
10 \% \\
\text { Glycerol }\end{array}$ & $\begin{array}{l}23 \% \text { PEG4000 } \\
18 \% \text { Propylene } \\
\text { glycol } \\
100 \mathrm{mM} \\
\text { Citrate, pH:4.9 }\end{array}$ & $P 21$ & $\begin{array}{l}\mathrm{a}=73.7 \\
\mathrm{~b}=73.3 \\
\mathrm{c}=80.9 \\
\alpha=\gamma=90^{\circ} \\
\beta=109^{\circ}\end{array}$ & $\begin{array}{l}\text { Singh et al. } \\
(2001)\end{array}$ \\
\hline Escherich & 51 & $\begin{array}{l}\text { available } \\
\text { at } 2.5 \AA\end{array}$ & & $\begin{array}{l}34 \% \\
\text { Ammonium } \\
\text { sulfate } \\
100 \mathrm{mM} \\
\mathrm{NaCl}, 35 \mathrm{mM} \\
\mathrm{Na}_{2} \mathrm{HPO}_{4} \\
9 \mathrm{mM} \mathrm{Citric} \\
\text { acid } \\
0.2 \mathrm{mM} \text { DTT, } \\
\text { pH:5.4 }\end{array}$ & & $P 43212$ & $\begin{array}{l}a=b= \\
105.1 \\
c=150.3\end{array}$ & $\begin{array}{l}\text { Hurley et } \\
\text { al. (1989) }\end{array}$ \\
\hline \multicolumn{9}{|c|}{ Subfamily II } \\
\hline \multicolumn{2}{|c|}{$\begin{array}{l}\text { Desulfotalea } \\
\text { psychrophila }\end{array}$} & $\begin{array}{l}\text { available } \\
\text { at } 1.75 \AA\end{array}$ & sdvd & $\begin{array}{l}\text { 10mM DL- } \\
\text { isocitrate } \\
0.25 \mathrm{mM} \\
\mathrm{NADP}^{+} \\
20 \mathrm{mM} \mathrm{Pi}^{-} \\
\text {buffer, pH:7.0 } \\
10 \mathrm{mM}^{-} \\
\mathrm{MgCl}_{2}\end{array}$ & $\begin{array}{l}\text { 100mM Tris- } \\
\mathrm{HCl}, \mathrm{pH}: 7.4 \\
1.7-1.9 \mathrm{M} \\
\text { Ammonium } \\
\text { sulfate } \\
2 \% \mathrm{PEG} 400 \\
60 \mathrm{mM} \mathrm{MgSO}_{4}\end{array}$ & $P 1$ & $\begin{array}{l}\mathrm{a}=59.3 \\
\mathrm{~b}=73.3 \\
\mathrm{c}=126.4 \\
\alpha=98.9^{\circ} \\
\beta=99.0^{\circ} \\
\gamma=113.9^{\circ}\end{array}$ & $\begin{array}{l}\text { Fedøy et al. } \\
(2007)\end{array}$ \\
\hline
\end{tabular}


(Continued)

\begin{tabular}{|c|c|c|c|c|c|c|c|c|}
\hline \multirow[b]{2}{*}{ Species } & \multirow{2}{*}{$\begin{array}{l}\text { Mol. } \\
\text { mass } \\
(\mathrm{kDa})\end{array}$} & \multirow{2}{*}{$\begin{array}{l}3 \mathrm{D} \\
\text { structure }\end{array}$} & \multicolumn{3}{|c|}{ Crystallization condition } & \multirow{2}{*}{$\begin{array}{l}\text { Space } \\
\text { group }\end{array}$} & \multirow{2}{*}{$\begin{array}{l}\text { Unit cell } \\
\text { dimen- } \\
\text { sion }(\AA)\end{array}$} & \multirow[b]{2}{*}{ Reference } \\
\hline & & & Method & $\begin{array}{l}\text { Protein } \\
\text { solution }\end{array}$ & Precipitant & & & \\
\hline \multicolumn{2}{|c|}{ Human cytosol } & $\begin{array}{l}\text { available } \\
\text { at } 2.7 \AA\end{array}$ & hdvd & & $\begin{array}{l}\text { 100mM MES } \\
\text { pH:6.5 } \\
12 \% \text { PEG20000 }\end{array}$ & $P_{43} 212$ & $\begin{array}{l}a=b= \\
82.7 \\
c=308.0\end{array}$ & $\begin{array}{l}\text { Xu et al. } \\
(2004)\end{array}$ \\
\hline & 46.7 & $\begin{array}{l}\text { available } \\
\text { at } 2.41 \AA\end{array}$ & hdvd & $\begin{array}{l}\text { 10mM DL- } \\
\text { isocitrate } \\
10 \mathrm{mM} \mathrm{CaCl}_{2} \\
10 \mathrm{mM} \\
\mathrm{NADP}\end{array}$ & $\begin{array}{l}\text { 100mM MES, } \\
\text { pH:5.9 } \\
20 \% \text { PEG6000 }\end{array}$ & $P 22_{1}$ & $\begin{array}{l}a=103.3 \\
b=86.7 \\
c=115.8 \\
\beta=107.2^{\circ}\end{array}$ & \\
\hline $\begin{array}{l}\text { Thermoto } \\
\text { maritime } \\
\text { (homote }\end{array}$ & $\begin{array}{c}\text { meric) } \\
45.4\end{array}$ & $\begin{array}{l}\text { available } \\
\text { at } 2.2 \AA\end{array}$ & sdvd & & $\begin{array}{l}\text { 16\% PEG6000 } \\
200 \mathrm{mM} \\
\mathrm{Na}^{-} \text {acetate } \\
50 \mathrm{mM} \mathrm{NaCl} \\
100 \mathrm{mM} \\
\text { Succinate, } \\
\text { pH:6.0 }\end{array}$ & $P 2_{1} 2_{1} 2_{1}$ & $\begin{array}{l}\mathrm{a}=62.5 \\
\mathrm{~b}=88.1 \\
\mathrm{c}=180.9 \\
\alpha=\beta=\gamma= \\
90^{\circ}\end{array}$ & $\begin{array}{l}\text { Karlström } \\
\text { et al. (2006) }\end{array}$ \\
\hline \multicolumn{9}{|c|}{ Subfamily III } \\
\hline \multicolumn{2}{|c|}{$\begin{array}{l}\text { porcine heart } \\
\text { mitochondria } \\
\text { (NADP }{ }^{+}- \\
\text {dependent) }\end{array}$} & & & $\begin{array}{l}\text { 100mM } \\
\text { Triethanol- } \\
\text { amine-HCl, } \\
\text { pH:7.7 } \\
100 \text { or } \\
400 \mathrm{mM} \\
\mathrm{Na}_{2} \mathrm{SO}_{4} \\
4 \mathrm{mM} \\
\text { Isocitrate } \\
2 \mathrm{mM} \mathrm{MnSO} 4\end{array}$ & $\begin{array}{l}16-20 \% \\
\text { PEG6000 } \\
100 \mathrm{mM} \\
\mathrm{Na}_{2} \mathrm{SO}_{4} \\
100 \mathrm{mM} \\
\text { Triethanol- } \\
\text { amine acetate, } \\
\text { pH:7.7 }\end{array}$ & $C 2$ & $\begin{array}{l}a=137.0 \\
b=113.4 \\
c=65.0 \\
\beta=98.5^{\circ}\end{array}$ & $\begin{array}{l}\text { Endrizzi et } \\
\text { al. (1996) }\end{array}$ \\
\hline & 45 & $\begin{array}{l}\text { available } \\
\text { at } 1.85 \AA\end{array}$ & hdvd & $\begin{array}{l}\text { 100mM } \\
\text { Triethanol- } \\
\text { amine-HCl, } \\
\text { pH:7.7 } \\
150 \mathrm{mM} \\
\mathrm{Na}_{2} \mathrm{SO}_{4} \\
8 \mathrm{mM} \mathrm{DL}- \\
\text { isocitrate } \\
4 \mathrm{mM} \mathrm{MnSO} 4\end{array}$ & $\begin{array}{l}\text { 100mM } \\
\text { Triethanol- } \\
\text { amine-HCl, } \\
\text { pH:7.7 } \\
150 \mathrm{mM} \\
\mathrm{Na}_{2} \mathrm{SO}_{4} \\
20 \% \mathrm{PEG} 6000 \\
3 \% \text { Glycerol }\end{array}$ & $C 2$ & $\begin{array}{l}a=138.0 \\
b=113.8 \\
c=66.8 \\
\beta=97.6^{\circ}\end{array}$ & $\begin{array}{l}\text { Ceccarelli } \\
\text { et al. (2002) }\end{array}$ \\
\hline \multirow{3}{*}{\multicolumn{2}{|c|}{$\begin{array}{l}\text { Thermus } \\
\text { thermophilus HB8 }\end{array}$}} & & & & $\begin{array}{l}\text { 10\% PEG6000 } \\
\text { 100mM Tris- } \\
\mathrm{HCl}, \mathrm{pH}: 8.5\end{array}$ & $\begin{array}{l}I 222 \text { or } \\
I 2{ }_{1} 2{ }_{1}{ }_{1}\end{array}$ & $\begin{array}{l}a=100.1 \\
b=150.4 \\
c=87.4\end{array}$ & $\begin{array}{l}\text { Ohzeki et } \\
\text { al. (1995) }\end{array}$ \\
\hline & & & hdvd & & $\begin{array}{l}100 \mathrm{mM} \mathrm{Na}^{-} \\
\text {cacodylate } \\
1.4 \mathrm{M} \mathrm{Na}^{-} \\
\text {acetate } \\
\text { pH: } 7.0\end{array}$ & $\mathrm{C} 2$ & $\begin{array}{l}a=495.5 \\
b=189.2 \\
c=336.2 \\
\beta=126.4^{\circ}\end{array}$ & $\begin{array}{l}\text { Ishii et al. } \\
\text { (2008) }\end{array}$ \\
\hline & & $\begin{array}{l}\text { available } \\
\text { at } 1.80 \AA\end{array}$ & & & & $P 22_{1}$ & $\begin{array}{l}a=c= \\
73.0 \\
b=95.2 \\
\beta=92.1^{\circ}\end{array}$ & $\begin{array}{l}\text { Lokanath } \\
\text { et al. }(2006)\end{array}$ \\
\hline
\end{tabular}


(Continued)

\begin{tabular}{|c|c|c|c|c|c|c|c|c|}
\hline \multirow{2}{*}{ Species } & \multirow{2}{*}{$\begin{array}{l}\text { Mol. } \\
\text { mass } \\
(\mathrm{kDa})\end{array}$} & \multirow{2}{*}{$\begin{array}{l}3 \mathrm{D} \\
\text { structure }\end{array}$} & \multicolumn{3}{|c|}{ Crystallization condition } & \multirow{2}{*}{$\begin{array}{l}\text { Space } \\
\text { group }\end{array}$} & \multirow{2}{*}{$\begin{array}{l}\text { Unit cell } \\
\text { dimen- } \\
\text { sion }(\AA)\end{array}$} & \multirow{2}{*}{ Reference } \\
\hline & & & Method & $\begin{array}{l}\text { Protein } \\
\text { solution }\end{array}$ & Precipitant & & & \\
\hline \multicolumn{3}{|c|}{$\begin{array}{l}\text { yeast } \\
\text { (in complex with } \\
\mathrm{NAD}^{+} \text {, octamer) }\end{array}$} & & $\begin{array}{l}10 \mathrm{mM} \text { Tris- } \\
\mathrm{HCl}, \mathrm{pH}: 7.4 \\
40 \mathrm{mM} \mathrm{NaCl} \\
10 \mathrm{mM} \mathrm{Na}^{-} \\
\text {citrate } \\
4 \mathrm{mM} \mathrm{MgCl}_{2} \\
5 \% \text { Glycerol }\end{array}$ & $\begin{array}{l}\text { 100mM Hepes } \\
900 \mathrm{mM} \mathrm{Na}^{-} \\
\text {citrate, } \mathrm{pH}: 7.5\end{array}$ & R3 & $\begin{array}{l}\mathrm{a}=302.0 \\
\mathrm{c}=112.1\end{array}$ & $\begin{array}{l}\text { Hu et al. } \\
(2005)\end{array}$ \\
\hline \multicolumn{9}{|c|}{ Other family, monomeric } \\
\hline \multicolumn{2}{|c|}{$\begin{array}{l}\text { Azotobacter } \\
\text { vinelandii } \\
\text { (in complex with } \\
\text { DL-isocitrate and } \\
\mathrm{Mg}^{2+} \text { ) }\end{array}$} & & & $\begin{array}{l}2.0-2.2 \mathrm{M} \\
\text { Ammonium } \\
\text { sulfate } \\
\mathrm{w} / \mathrm{o} \\
1 \mathrm{mM} \\
\text { Isocitrate } \\
1 \mathrm{mM} \mathrm{MgCl} 2 \\
\text { or } 1.8 \mathrm{M} \\
\text { Phosphate }\end{array}$ & $\begin{array}{l}1.6 \mathrm{M} \\
\text { Ammonium } \\
\text { sulfate } \\
\text { or 1.4M Na-K } \\
\text { phosphate }\end{array}$ & $P 42212$ & $\begin{array}{l}\mathrm{a}=\mathrm{b}= \\
122.1 \\
\mathrm{c}=163.9 \\
\alpha=\beta= \\
\gamma=90^{\circ}\end{array}$ & $\begin{array}{l}\text { Czerwizski } \\
\text { et al. (1977) }\end{array}$ \\
\hline & $80-100$ & $\begin{array}{l}\text { available } \\
\text { at } 1.95 \AA\end{array}$ & & $\begin{array}{l}20 \mathrm{mM} \mathrm{K}^{-} \\
\text {phosphate, } \\
\text { pH:6.8 } \\
2 \mathrm{mM} \mathrm{MgCl} 2 \\
10 \% \\
\text { Glycerol } \\
\text { 10mM 2- } \\
\text { Mercapto- } \\
\text { ethanol }\end{array}$ & $\begin{array}{l}\text { 100mM Hepes- } \\
\text { NaOH, pH:7.0 } \\
24 \% \text { PEG6000 } \\
20 \% \text { Glycerol } \\
4 \mathrm{mM} \mathrm{MnCl} 2 \\
4 \mathrm{mM} \mathrm{DL-} \\
\text { isocitrate }\end{array}$ & $P 2_{1} 2_{1} 2_{1}$ & $\begin{array}{l}a=108.4 \\
b=121.7 \\
c=129.7\end{array}$ & $\begin{array}{l}\text { Yasutake } \\
\text { et al. }(2001)\end{array}$ \\
\hline \multicolumn{2}{|c|}{$\begin{array}{l}\text { Corynebacterium } \\
\text { glutamicum }\end{array}$} & & & $\begin{array}{l}\text { 2.5M MES, } \\
\text { pH:6.8 } \\
1.25 \mathrm{mM} \\
\mathrm{MnCl}_{2} \\
1.25 \mathrm{mM} \text { DTT } \\
5 \% \text { Glycerol }\end{array}$ & $\begin{array}{l}\text { 25\% PEG2000 } \\
\text { monomethyl- } \\
\text { ether } \\
180 \mathrm{mM} \mathrm{MgCl}_{2} \\
100 \mathrm{mM} \text { Tris- } \\
\mathrm{HCl}, \mathrm{pH}: 7.2\end{array}$ & $\mathrm{C} 2$ & $\begin{array}{l}a=137.1 \\
b=54.6 \\
c=126.4 \\
\beta=108^{\circ}\end{array}$ & $\begin{array}{l}\text { Audette et } \\
\text { al. (1999) }\end{array}$ \\
\hline & 80 & $\begin{array}{l}\text { available } \\
\text { at } 1.75 \AA\end{array}$ & & & $\begin{array}{l}25 \% \text { PEG2000 } \\
\text { monomethyl- } \\
\text { ether } \\
200 \mathrm{mM} \mathrm{MgCl}_{2} \\
100 \mathrm{mM} \text { Tris- } \\
\mathrm{HCl}, \mathrm{pH}: 7.2\end{array}$ & $\mathrm{C} 2$ & $\begin{array}{l}a=129.0 \\
b=52.7 \\
c=124.0 \\
\beta=108.9^{\circ}\end{array}$ & $\begin{array}{l}\text { Imabaya- } \\
\text { shi et al. } \\
(2006)\end{array}$ \\
\hline
\end{tabular}

*hdvd: hanging drop vapor diffusion method, sdvd: sitting drop vapor diffusion method.

Table 1. Summary of crystallization conditions for ICDHs reported so far. 
Hofmeister series, the order of effectiveness of the salts (Kunz et al., 2004), the crystallization conditions reported for ICDHs, and so on, were taken into account. Crystallization conditions for ICDHs from several different microorganisms reported so far are summarized in Table 1 with classification to the subfamilies. It may be instructive to show some more details observed on our screening stages. Figure 2 shows the results when 35\% saturated ammonium sulfate was used as the precipitant. The reservoir solution contained $35 \%$ saturated ammonium sulfate, $0.1 \mathrm{M}$ sodium chroride, $35 \mathrm{mM}$ disodium hydrogenphosphate, $9 \mathrm{mM}$ citric acid, and $0.2 \mathrm{mM}$ dithiothreitol. Although no crystalline substances were recognized at $\mathrm{pH} 5.0$, pillar-shaped thin crystals gathered together forming a dumbbell-like architecture were seen. These dumbbell-like architectures were frequently observed over the wide $\mathrm{pH}$ range between $\mathrm{pH} 5.2$ and 7.5. Sometimes those were aggregated in a higher $\mathrm{pH}$ region. Tth $\mathrm{ICDH}$ showed a strong tendency to form pillar-like crystals under the conditions in which ammonium sulfate or 2-methyl-2,4-pentanediol was used as a precipitant. These are shown in Fig. 3. Even under conditions that contained DLisocitric acid or citric acid, Tth ICDH formed thin stick-like or pillar-like crystals (Fig. 4). We have found conditions under which Tth ICDH forms crystals that diffract X-ray beyond $4 \AA$ resolution, as such in a rod-like shaped (crystal form I) (Fig. 4) and a monoclinic diamond shaped (crystal form II) (Fig. 5). In the condition for crystal form I, the reservoir solution contained $100 \mathrm{mM}$ sodium cacodylate, $1.4 \mathrm{M}$ sodium acetate, $10 \mathrm{mM}$ citric acid and $10 \mathrm{mM}$ $\mathrm{MnCl}_{2}$ with $\mathrm{pH}$ of 6.5 through 7.8. The reservoir solution containing $10 \mathrm{mM}$ DL-isocitric acid instead of $10 \mathrm{mM}$ citric acid is similar to the condition for crystal form $\mathrm{I}$, the remainder of

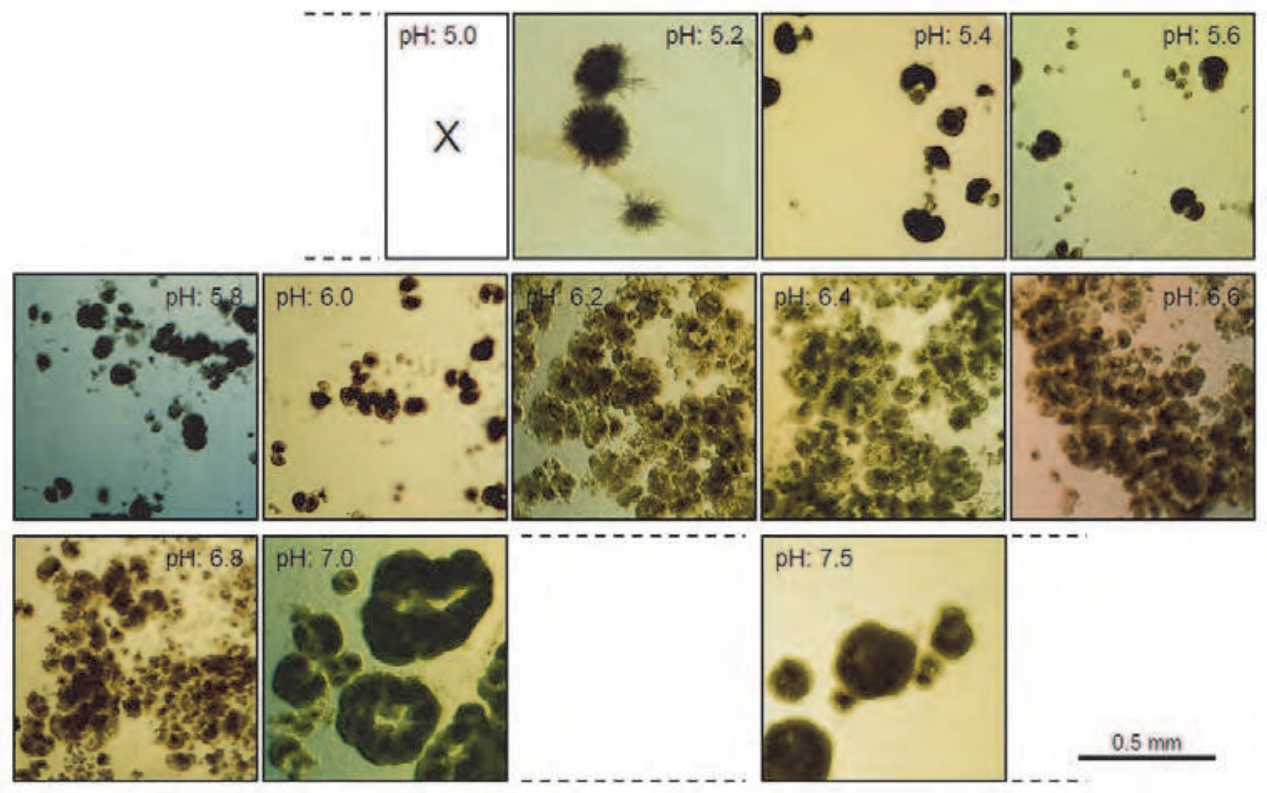

Fig. 2. Crystallization condition screening results of Tth ICDH using saturated ammonium sulfate as the precipitant. Pillar-shaped thin crystals forming dumbbell-like architectures were seen over the wide $\mathrm{pH}$ range. The ' $\mathrm{X}$ ' means that no crystals were observed. 

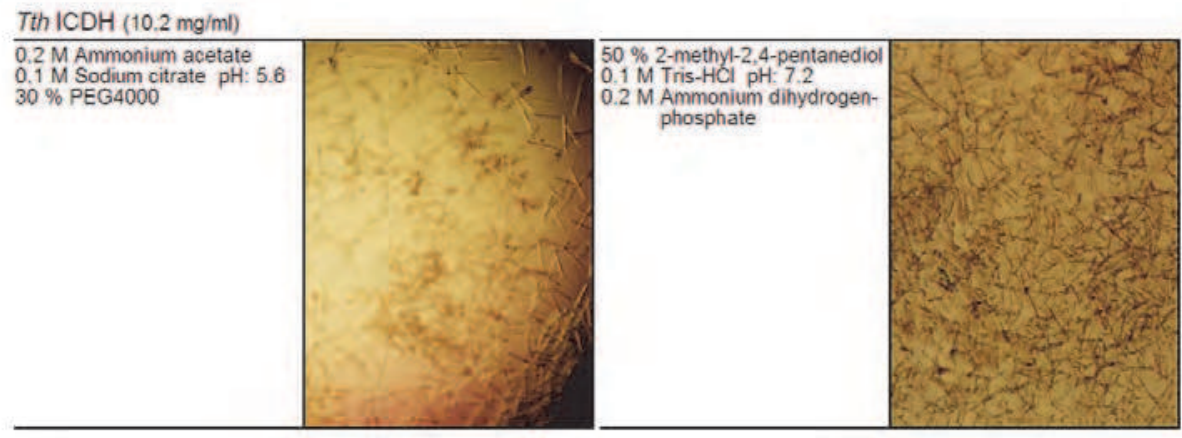

$0.5 \mathrm{~mm}$

Fig. 3. Pillar-shaped crystals of Tth ICDH obtained by using PEG4000 or MPG as the precipitant. Each reservoir condition is indicated. A lot of thin rod-shaped crystals were observed under each condition. However, those were too thin and not suitable for X-ray diffraction experiment.

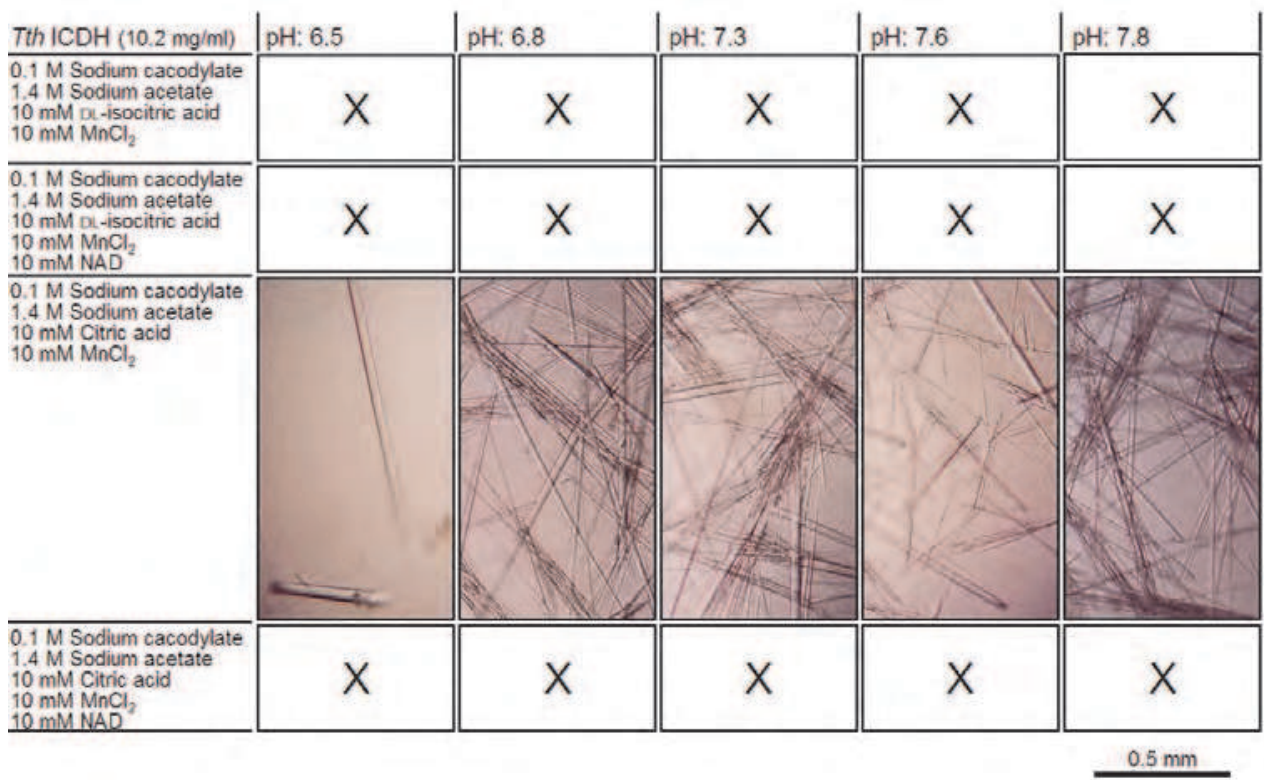

Fig. 4. Crystallization condition screening results of Tth ICDH using sodium acetate as the precipitant. Rod-shaped crystals (crystal form I) were obtained in the reservoir solution containing $0.1 \mathrm{M}$ sodium cacodylate, $1.4 \mathrm{M}$ sodium acetate, $10 \mathrm{mM}$ citric acid, and $10 \mathrm{mM}$ $\mathrm{MnCl}_{2}$. The ' $\mathrm{X}$ ' means that no crystals were observed.

$100 \mathrm{mM}$ sodium cacodylate, $1.4 \mathrm{M}$ sodium acetate, and $10 \mathrm{mM} \mathrm{MnCl} 2$ was common, and no crystals appeared in the $\mathrm{pH}$ range of 6.5 through 7.8. An addition of $10 \mathrm{mM}$ NAD was also 
useless. Furthermore, the addition of $10 \mathrm{mM}$ NAD to the exact condition for crystal form I resulted in no crystal formation (Fig. 4). In the condition for crystal form II, the reservoir solution contained $100 \mathrm{mM}$ sodium cacodylate and $1.4 \mathrm{M}$ sodium acetate with wide range of $\mathrm{pH}$ condition of 6.1 through 8.4 (Fig. 5). As one can see at pH 8.1 in Fig. 5, multiple crystal forms are sometimes seen coexisting in the same sample of mother liquor. Crystals in the size up to $0.3 \times 0.3 \times 0.1 \mathrm{~mm}^{3}$ were frequently observed within one month at $298 \mathrm{~K}$. The crystals seemed to grow faster and larger in a fairly basic $\mathrm{pH}$ region. As shown in Fig. 6, the addition of $10 \mathrm{mM}$ DL-isocitric acid or $10 \mathrm{mM}$ citric acid facilitated the aggregate formation of pillar-shaped crystals. No crystals were formed upon the supplement of $10 \mathrm{mM} \mathrm{MgCl}_{2}$ to each of the above conditions (Fig. 6). Tth ICDH crystals in crystal form II incubated at the condition for 8 years showed clear edges even though amorphous precipitates were increased (data not shown). It has been said that a protein from a thermophilic bacterium is proportionally thermostable. We are convinced that this is true even in the crystal state.

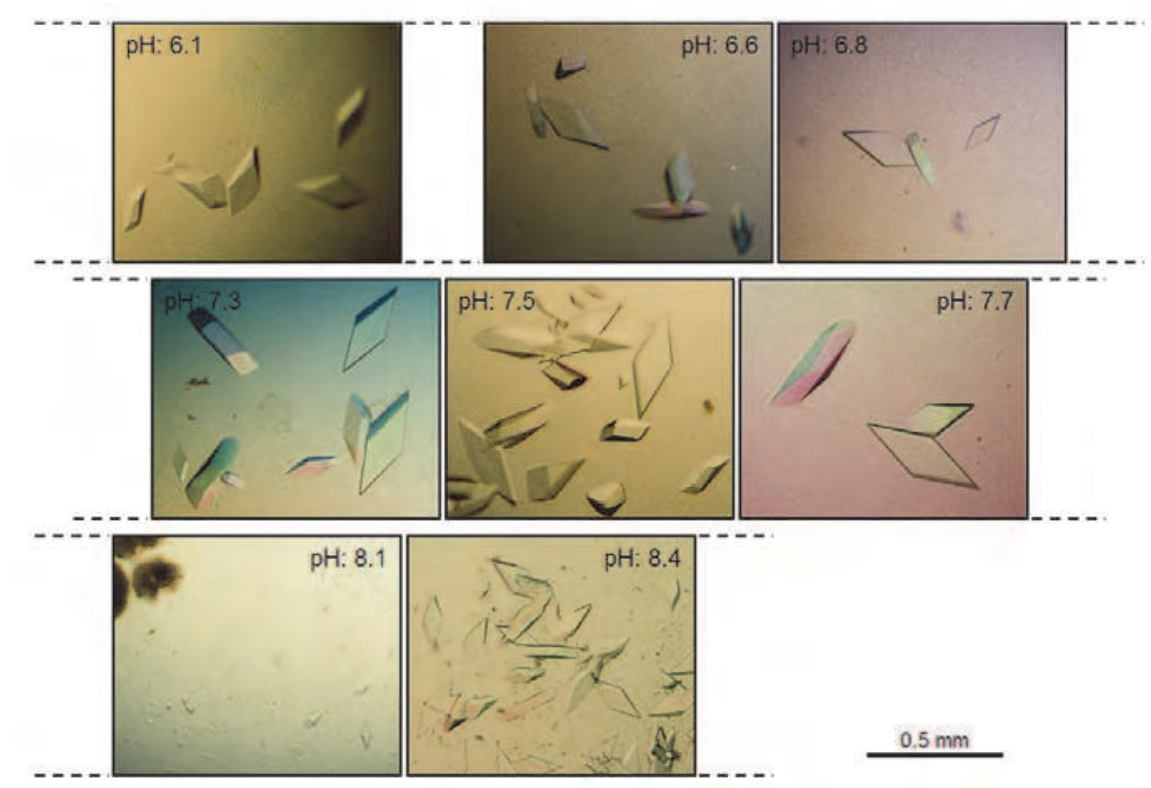

Fig. 5. Crystallization condition screening results of Tth ICDH using sodium acetate as the precipitant. The thick diamond-shaped crystals (crystal form II) were obtained in the reservoir solution containing $100 \mathrm{mM}$ sodium cacodylate and $1.4 \mathrm{M}$ sodium acetate with wide range of $\mathrm{pH}$ condition of 6.1 through 8.4 .

X-ray diffraction experiments were carried out at three different facilities; The diffraction data from both crystal form I and II up to middle range resolution were collected at $286 \mathrm{~K}$ on a Rigaku R-AXIS IIc image plate detector (Rigaku Corp., Tokyo, Japan) in our laboratory (AIST, Tsukuba, Japan) equipped with a Rotaflex FR rotating anode generator operated at 45 $\mathrm{kV}, 50 \mathrm{~mA}$ with focal spot size of $0.1 \mathrm{~mm}$. The image data obtained were processed with a program set incorporated in the R-AXIS IIc software package. The cryogenic X-ray diffraction experiments with crystal form I were carried out at the BL-6A beamline station of 


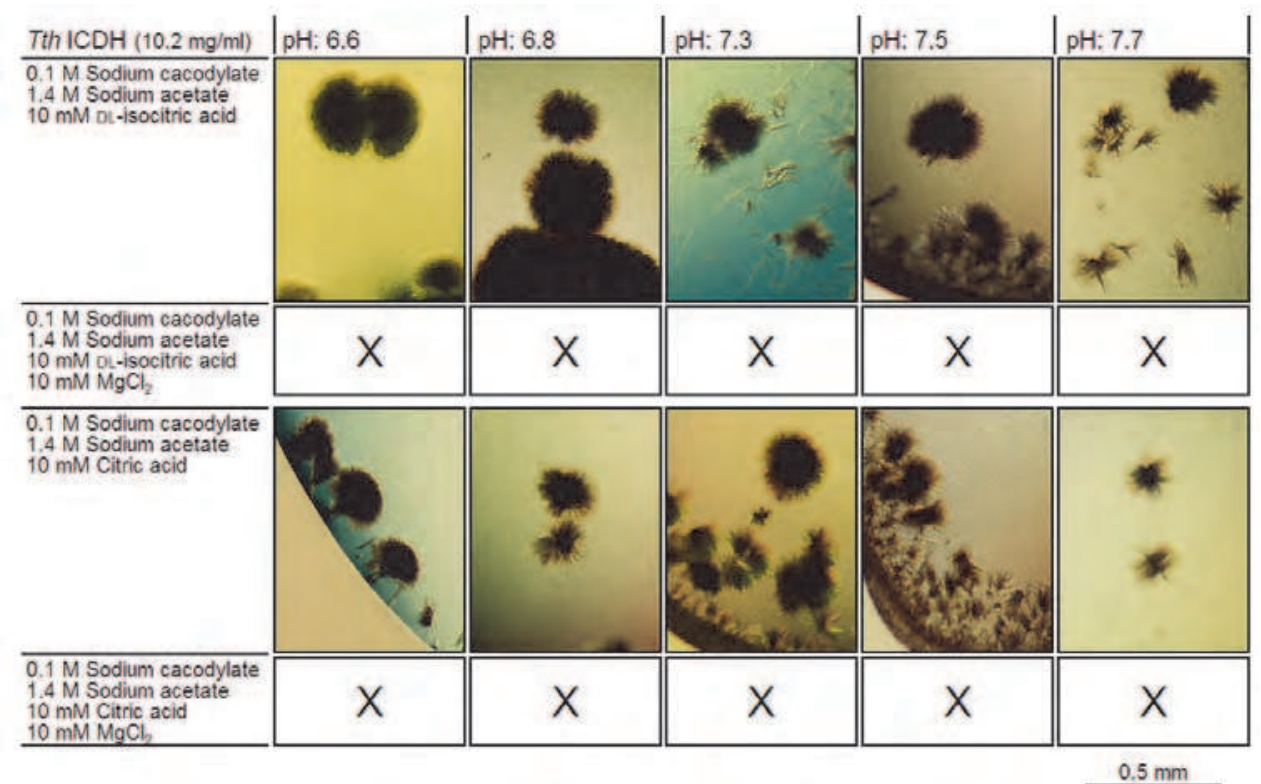

Fig. 6. Crystallization condition screening results of Tth ICDH using sodium acetate as the precipitant. In the presence of $10 \mathrm{mM}$ DL-isocitric acid, or $10 \mathrm{mM}$ citric acid, pillar-shaped thin crystals forming dumbbell-like architectures were seen over the wide $\mathrm{pH}$ range.

However, in a co-addition of $10 \mathrm{mM} \mathrm{MgCl}_{2}$ to each condition, no crystalline substances were observed. The ' $X$ ' means no crystals observed.

the Photon Factory (KEK, Tsukuba, Japan). The intensity data were collected at $105 \mathrm{~K}$. The X-ray beam was monochromatized to $1.00 \AA$ with an Si (111) monochromator, and an aperture collimator of $0.10 \mathrm{~mm}$ diameter was used. Oscillation photographs were taken by the ADSC Quantum 4R CCD detector. The oscillation range was $5^{\circ}$ during a 10 -min exposure and the distance from the crystal to the CCD detector was $300 \mathrm{~mm}$. The data were processed using DPS/MOSFLM (Leslie, 1992) and programs from the CCP4 suite (Collaborative Computing Project, 1994). Another measurement with crystal form II was performed at $293 \mathrm{~K}$ on a Rigaku R-AXIS IV (Rigaku Corp., Tokyo, Japan) using synchrotron radiation at the BL-24 station in the SPring-8 (JASRI, Hyogo, Japan) with X-rays of wavelength $0.835 \AA$. The oscillation range during a 3-min exposure was $0.5^{\circ}$ and the distance from the crystal to the CCD detector was $300 \mathrm{~mm}$. The exposed images were automatically analyzed with an incorporated R-AXIS IV software package.

The cryogenic X-ray diffraction data were obtained from the crystal form I at BL-6A beamline station in KEK. Preliminary intensity data were collected in which the diffraction extended beyond $3.4 \AA$ resolution. The crystal in form I was assumed to be hexagonal or trigonal, and the unit dimensions were $\mathrm{a}=\mathrm{b}=163.1 \AA, \mathrm{c}=269.1 \AA, \alpha=\beta=90.0^{\circ}, \gamma=120.0^{\circ}$. Further measurement has been hampered by the cryoprotectants selected and used. The crystal form II diffracted X-rays beyond $4 \AA$ at the BL-24 station in SPring- 8 using the synchrotron X-ray source. Including diffraction data obtained with Rigaku R-AXIS IIc in the laboratory Tth ICDH crystal was determined to be monoclinic and belonged to $C 2$ space 
group. The unit cell dimensions were $\mathrm{a}=495.5 \AA, \mathrm{b}=189.2 \AA, \mathrm{c}=336.2 \AA, \beta=126.4^{\circ}$. According to the normal $V_{m}$ range of 1.7 - $3.5 \AA^{3} \mathrm{Da}^{-1}$ (Matthews, 1968), the asymmetric unit was estimated to contain between 33 and $68 \mathrm{Tth} \mathrm{ICDH}$ molecules with a molecular mass of $54.2 \mathrm{kDa}$. The calculation indicates that Tth ICDH crystal form II contains large number of molecules in the reiterative unit in the crystalline arrays. This fact can be reconciled with the result observed in the non-denaturing PAGE; several bands were stained in the higher molecular mass region in addition to the native band corresponding to Tth ICDH dimer in the non-denaturing gel, which were performed on the crystals gathered by centrifugation followed by rapid loading to the stacking gel prior to the application of voltage (data not shown). However, in the PAGE with moderate treatment for the crystals gathered by the centrifugation, the band that corresponded to the molecular mass of the dimer became dominant. These observations can be understood as follows: the crystals are made of large preformed homo-complexes of Tth ICDH molecules, which stay stable in the reservoir solution, but soon dissociate into the sub-clusters or singler molecules (Tth ICDH dimers) out of the range of the critical crystallization condition.

As to the manner of interaction between the possible supramolecules' packing in the crystals, interesting results were obtained. The thick diamond-shaped crystals grown at around neutral $\mathrm{pH}$ region, $\mathrm{pH} 7.5$ for example, was found to maximally diffract $\mathrm{X}$-rays at around $7.0 \AA$ at $95 \mathrm{~K}$ after treatment with reservoir solution plus $15 \%$ glycerol as a cryoprotectant. Furthermore, the crystals in form II, having the same appearance, grown in the slightly basic $\mathrm{pH}$ region, $\mathrm{pH} 7.8,8.1$ and 8.4, for example, could never diffract $\mathrm{X}$-rays at $95 \mathrm{~K}$. These observations could be understood in that the formation of the supramolecular units and the interaction between the units were suitable enough to form the form II crystal shape at room temperature, which could be further inferred from the diffraction images in high resolution range (data not shown). When the crystals were treated at cryogenic condition, the intermolecular interactions should have been altered in the direction of increasing entropy (N. Ishii et al., 2008).

Tth ICDH molecules were placed under the crystallization condition for about three months and the protein forming crystal form II were examined as they were at the state with HPLC gel filtration chromatography using a TSKgel G3000SWxl (Tosoh, Tokyo, Japan). The elution profile of the above protein solution co-existing with form II crystals is shown in Fig. 7. There appeared a few peaks, which were labeled $1(\sim 400 \mathrm{kDa}), 2(\sim 300 \mathrm{kDa})$, and $3(\sim 220 \mathrm{kDa})$ in the molecular mass region larger than the intact Tth ICDH dimer (peak $4(98 \mathrm{kDa}))$. According to the molecular mass calibration standard, it is comprehensive that the peak 1, 2, and 3 correspond to octamer (presumably 4 dimers), hexamer (3 dimers), and tetramer (2 dimers), respectively. There seems to be hierarchies divisible by integers of the dimer as a unit.

Atomic force microscopy (AFM) gives us useful information on the growth and disorder of macromolecular crystal, and when combined with X-ray diffraction study can bring further insights into the improvement of the macromolecular crystallization protocols (Malkin \& Thorne, 2004; Scabert et al., 1995). Separately, we have performed AFM scanning on the crystalline surface of crystal form II. A lot of ellipsoidal bodies were observed (N. Ishii et al., 2008). The average values of the short and long axes of the ellipsoidal bodies detected in AFM imaging are $10.87 \pm 1.47,18.61 \pm 2.58 \mathrm{~nm}$, respectively. Therefore, the average volume of the body should be $1151.34 \pm 2.92 \mathrm{~nm}^{3}$. According to the normal $\mathrm{V}_{\mathrm{m}}$ range of $1.7-3.5 \AA^{3}$ $\mathrm{Da}^{-1}$ (Matthews, 1968), the molecular mass of the ellipsoidal body should fall in between 340 $\mathrm{kDa}$ and $700 \mathrm{kDa}$. These values can be ascribed to hexamer and dodecamer of Tth ICDH 


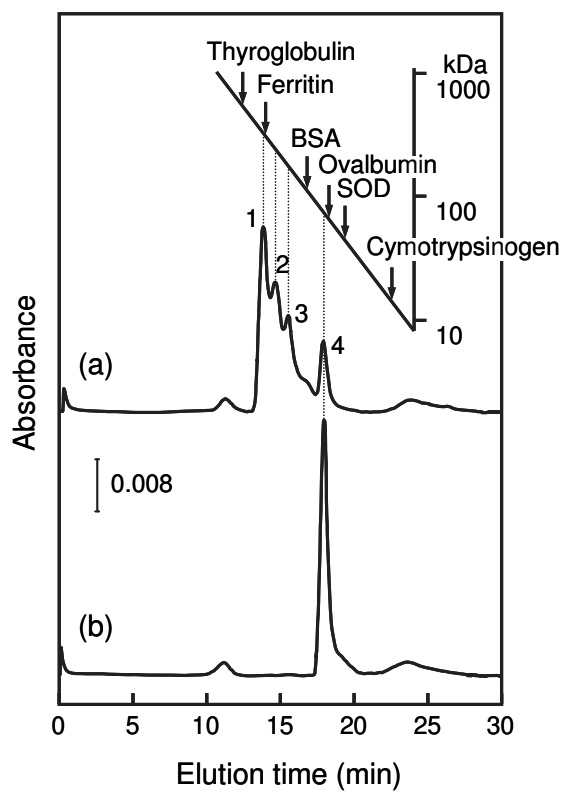

Fig. 7. HPLC gel permeation profiles of Tth ICDH solution with and without the thick diamond-shaped crystals (crystal form II). (a) HPLC gel permeation profile of Tth ICDH being incubated under the crystallization condition for crystal form II; (b) that of intact Tth ICDH. The peaks numbered 1, 2, 3, and 4 correspond to about $400 \mathrm{k}$, about $300 \mathrm{k}$, about 220 $\mathrm{k}$, and about $98 \mathrm{kDa}$ respectively.

(monomer) molecules, respectively. Since protein crystals usually include solvent molecules at high content it is difficult to speculate how many Tth ICDH molecules constitute the one ellipsoidal body. Taking these results obtained from AFM imaging and HPLC gel filtration into account, one can infer that Tth ICDH crystal form II should be comprised of oligomeric building blocks piled one on top of another. The building unit is most likely an octamer (4 dimers), and the next likely to be a hexamer (3 dimers) from the HPLC profile (Fig. 7), where both are made of Tth ICDH dimer as a basic unit. In crystal form II of Tth ICDH the exact arrangement and manner of the formation are still obscure, although there is possibility that Tth ICDH supramolecular complex acts as a block that interacts together in the process of spontaneous building up of form II crystals under the favorable crystallization condition described above. Needless to say, in order to determine a crystal structure of a certain protein species by X-ray method, crystals that well diffract X-rays to high resolution, and at the same time, that contain possibly small number of molecules in crystallographic asymmetric unit are prerequisite (N. Ishii et al., 2000a, 2000b; Shimamura et al., 2004). On the other hand, to construct some architectures in the nano-scale using protein molecules as building blocks we have to understand the nature of interactions between protein molecules, namely, how the 
ability to self-assembly emerges, including effects mediated through solvent conditions such as $\mathrm{pH}$, temperature and ionic strength, and so on (Biswas et al., 2009; D. Ishii et al., 2003). The result mentioned above have shed light on the usefulness of $T$ th $\mathrm{ICDH}$, a thermostable protein and its form II crystals, in the study of supramolecular complexes and crystal formation by self-assembly. It is apparent that research in this avenue needs to be continued further for elucidation of useful tools useable in protein nanotechnology.

\section{Crystal structure of ICDH}

ICDH evolved early and is widely distributed among archaea, bacteria, and eukarya. Such an evolutional trace can be found in diverse primary structures, various oligomeric forms taken, and different specificity as to cofactors (Steen et al., 2001). It has been proposed that $\mathrm{NAD}^{+}$-specific ICDH may be an ancestor enzyme that functions in $\mathrm{CO}_{2}$ fixation in an early stage of evolution of the Krebs cycle (Shiba et al., 1985).

We have unexpectedly obtained the crystals (form II) of the supramolecular complex of Tth ICDH and concentrated on surveying how these building block molecules pile up and selfassemblize into the crystal form II. Finally we have revealed the mechanism of the hierarchical formation that Tth ICDH molecules reside, being piled one on top another as a preformed supramolecular nano-architecture in the crystal lattice. In the mean time, Lokanath \& Kunishima (2006) successfully determined the structure of Tth ICDH at $1.8 \AA$ resolution. It should be instructive to mention an overview of typical ICDH structures, and what are still obscure and open to discussion from the view of structural biology and enzymology of ICDHs picking up some representatives.

\subsection{Escherichia coli ICDH}

The ICDH are usually dimeric proteins with two identical subunits of molecular mass of 40 $50 \mathrm{kDa}$ per subunit (Chen \& Gadal, 1990). In E. coli, ICDH is a homodimeric enzyme and its inactivation mechanism by phosphorylation has been reported in detail with regards to the crystal structure (Hurley et al., 1990). The crystal structure of ICDH from E. coli (Ec ICDH) shows that the substrate binding pockets and catalytic sites of the dimeric enzymes are formed from side chains of residues donated asymmetrically both subunits (Hurley et al., 1989). The tertiary structure of $E c$ ICDH is depicted in Fig. 8. The enzyme is composed of 13 $\alpha$-helices and $14 \beta$-strands. It contains three domains consisting of a large domain, a small domain, and a clasp domain. This manner is common to ICDH from Bacillus subtilis (Bs ICDH) and Tth ICDH. This enzyme has an active site in a cleft between the large and small domains (Hurley et al., 1994; Stoddard et al., 1993). The reaction mechanism of ICDH has been extensively studied in E. coli ICDH. A conformational change occurs from an open to closed form upon the binding of $\mathrm{NADP}^{+}$and the substrate. In the proposed mechanism, a proton is removed from the $\alpha$-hydroxyl group of isocitrate, and then, a hydride ion is transferred in a stereospecific way from the $\alpha$-carbon atom of the substrate to C- 4 of the nicotinamide ring of $\mathrm{NADP}^{+}$, oxidizing isocitrate to oxalosuccinate. In the following step, the $\beta$-carboxylate group of oxalosuccinate is removed as $\mathrm{CO}_{2}$, and is replaced by a proton in a stereospecific way to form 2-oxoglutarate. During both transitions the negative charge on the hydroxyl oxygen atom of isocitrate is stabilized by a magnesium ion. There are still controversies as to the mechanisms of the initial proton abstraction and the final proton donation. 
The crystal structure of Ec ICDH determined with its substrates revealed that the malate moiety of isocitrate, namely 1-carboxyl and 3-carboxyl groups and 2-hydroxyl group, is recognized by three arginine, three aspartate, one lysine, and one tyrosine residues of ICDH, which are the residues conserved between the enzymes (Hurley et al., 1990). As shown in Fig. 9, in the substrate binding site, the $\alpha$-carboxyl group of isocitrate is bound to three arginine residues, Arg-119, Arg-129, and Arg-153. The $\beta$-carboxylate group is bound to Arg153 and Tyr-160. The $\alpha$-position of isocitrate forms hydrogen bonds with the Lys-230', and Asp-283' residues of the other subunit of the dimer (Doyle et al., 2001; Mesecar et al., 1997).

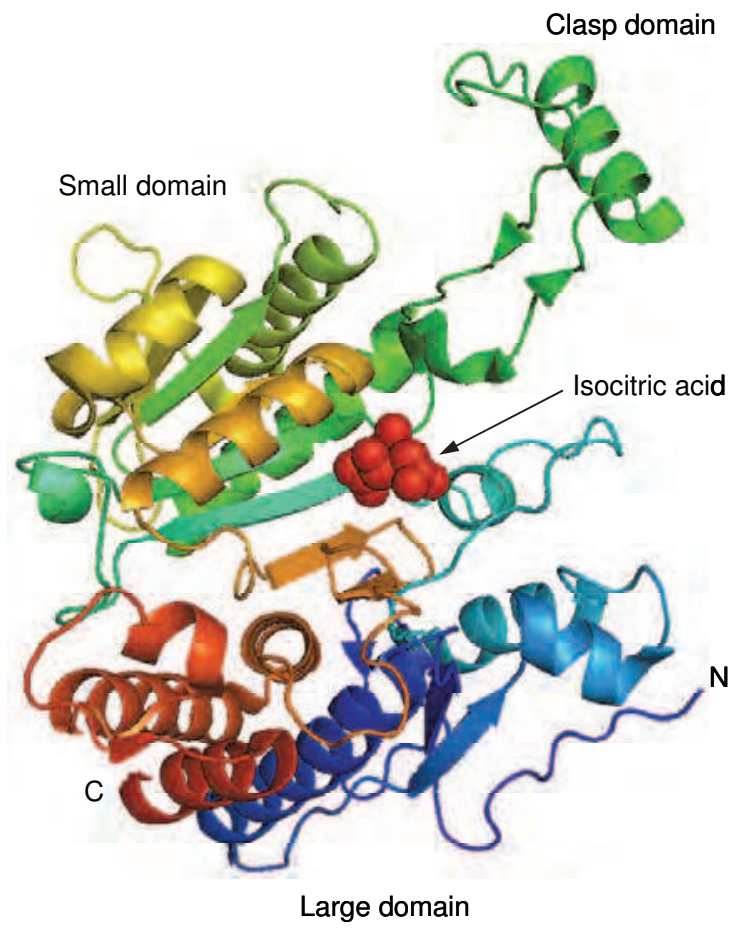

Fig. 8. Diagram of Ec ICDH monomer with isocitric acid. (PDB ID: 1P8F). The large domain containing the $\mathrm{N}$ and $\mathrm{C}$ termini, the small domain, and the clasp domain are indicated.

Atomic coordinates were obtained from the RCSB Protein Data Bank (www.rcsb.org/pdb/home/home.do) and imaged using PyMol (The PyMOL Molecular Graphics System, version 0.99, DeLano scientific, LLC).

Mesecar and Koshland Jr. have made precisely explanation as to the mechanism for stereospecificity, that is, to distinguish between the two enantiomers on the basis revealed by electron density maps of the crystal structures of ICDH with L- and D-isomer isocitrate (Mesecar \& Koshland Jr., 2000). In the metal-free crystal of ICDH with a racemic mixture of isocitrate, only the L-isomer $(2 \mathrm{~S}, 3 \mathrm{R})$ is seen bound to the enzyme. When enzyme crystals are 
presented with a racemic mixture of isocitrate in the presence of $\mathrm{Mg}^{2+}$, only D-isomer is seen in the active site in the crystal structure. They indicate the importance of the -OH group of L-isocitrate association with arginine residue at position 119 in the metal-free enzyme, in contrast to the $-\mathrm{OH}$ group of $\mathrm{D}$-isocitrate association with the metal and with two aspartate residues at position $283^{\prime}$ and 307.

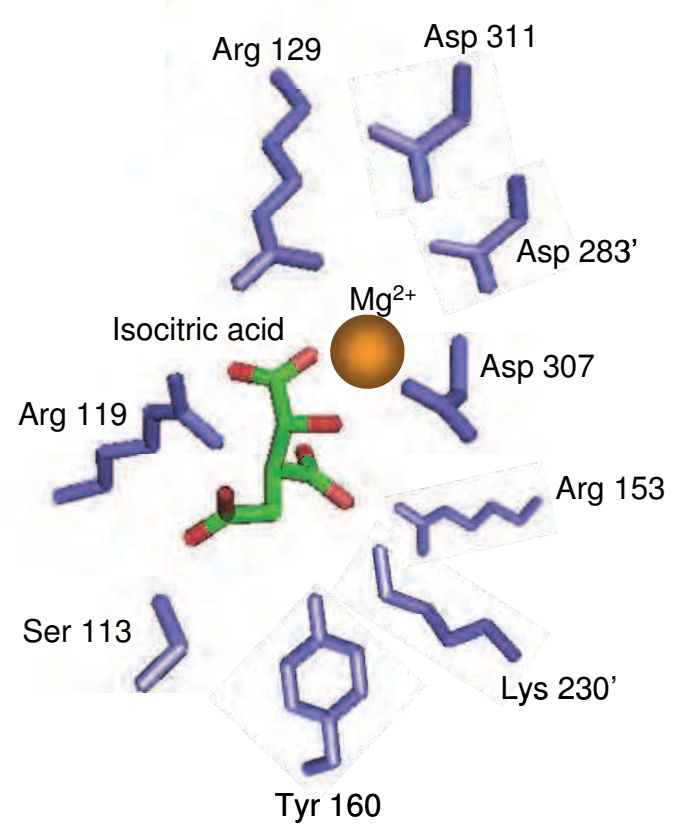

Fig. 9. Overview of the ICDH substrate binding site.

\subsection{Bacillus subtilis ICDH}

Recently, the crystal structure of $B s$ ICDH has been reported and discussed on the difference between $E_{c}$ ICDH. Both have very similar 3-D structures not only because Bs ICDH is $67 \%$ identical to $E c$ ICDH but also that both are $100 \%$ identical in the primary sequence around the phosphorylation site (Singh et al., 2001). The tertiary structure of Bs ICDH monomer A is illustrated in Fig. 10, and the Bs ICDH dimer is shown in Fig. 11. Each subunit is composed of $15 \alpha$-helices and $13 \beta$-strands. Although $B s$ ICDH is a homodimer, interestingly, the crystal structures of the individual monomers are not identical. In the dimerization, socalled clasp domain is formed where constituent of two $\beta$-strands and connecting $\alpha$-helix of each subunit interlock forming a hydrophobic core. The manner of intersubunit interactions in $B s$ ICDH dimer is reported the same for the most part with Ec ICDH. There are several reported differences between $B s \mathrm{ICDH}$ and $E c \mathrm{ICDH}$, suggesting the robustness of the enzyme in preserving the principle function. 


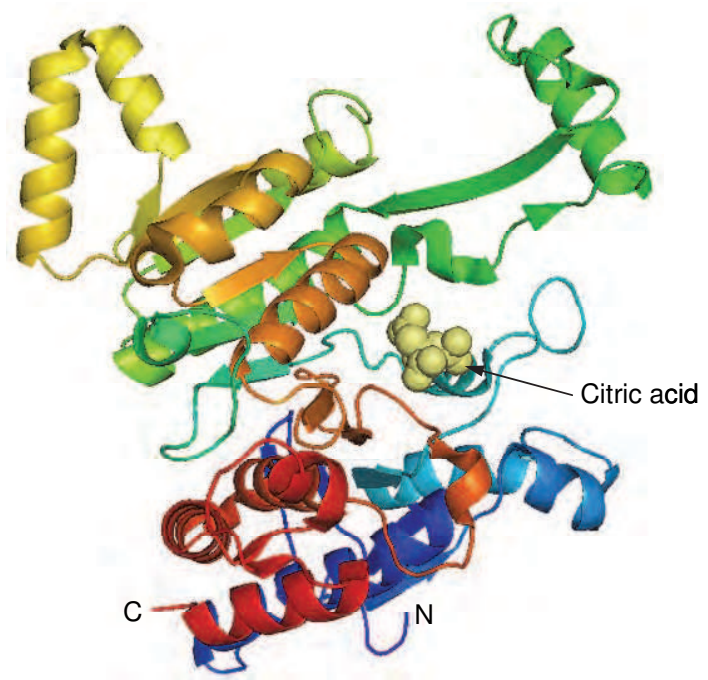

Fig. 10. $C \alpha$ trace of $B s$ ICDH monomer (monomer A) with citric acid. (PDB ID: 1HQS). Overall folding manner of the monomer resembles that of $E c \mathrm{ICDH}$, but has several differences in the secondary structures.

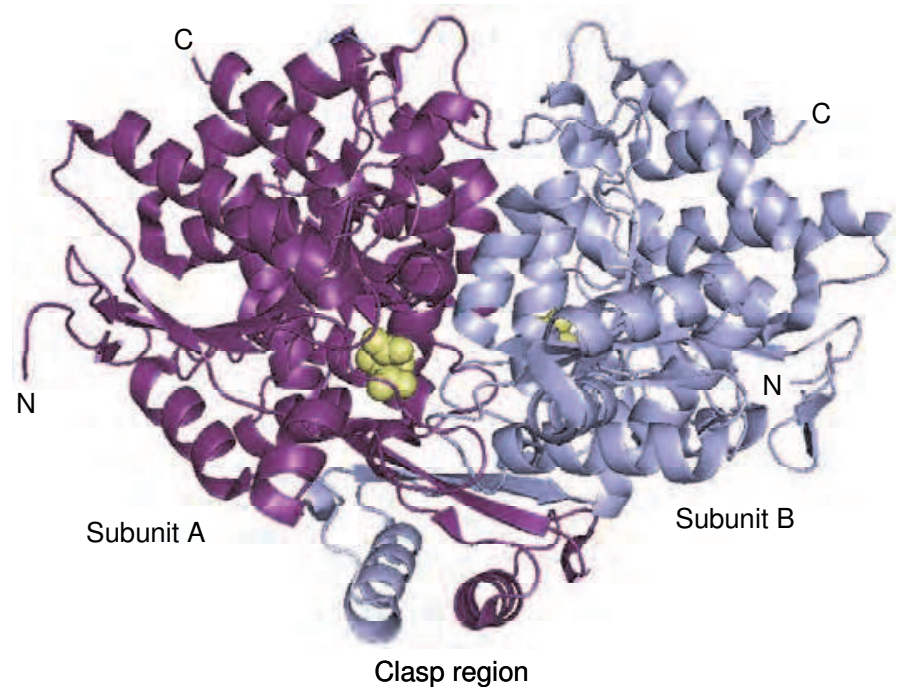

Fig. 11. Diagram of Bs ICDH dimer. Each of monomer A, and monomer B having slightly different conformation are related by dimerization mediated through expansive portion of small and clasp domains. (PDB ID: 1HQS). 


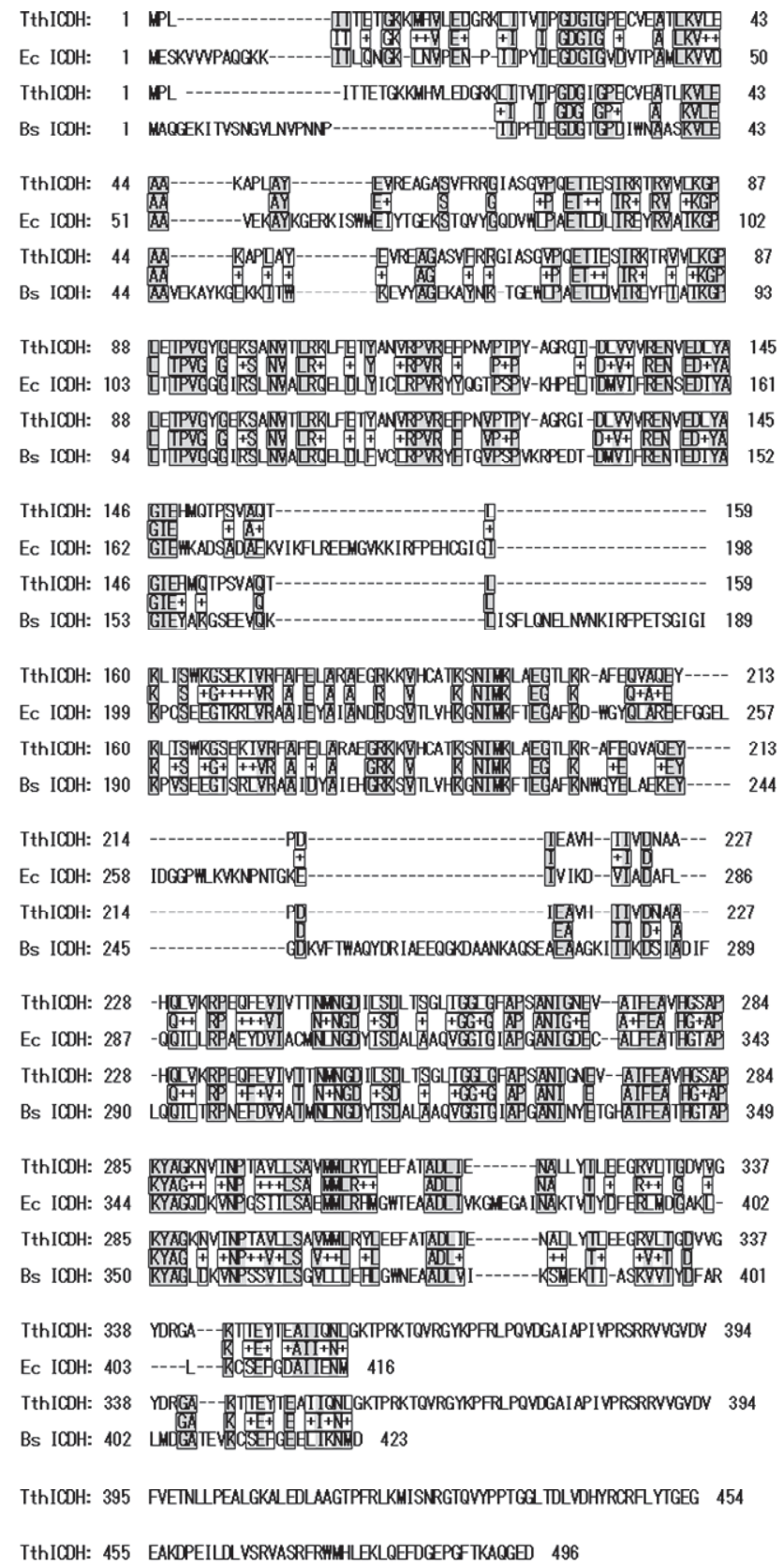

Fig. 12. Amino acid sequence alignment of Tth ICDH, Ec ICDH, and Bs ICDH. The shaded and boxed sequences represent those identical to $T$ th $\mathrm{ICDH}$ sequence, and boxed ones represent those in similar to $T$ th $\mathrm{ICDH}$ sequence. 


\subsection{Thermus thermophilus ICDH}

Between T. thermophilus and E. coli ICDHs, the residues of $37 \%$ are identical and those of $51 \%$ show similarity. The typical difference in the primary structure between the two enzymes is the presence of 141 extra residues at the C terminus in Tth ICDH. The region may contribute to the folding of the enzyme and the acquired thermostability of the enzyme (Miyazaki et al., 1992). Between Tth ICDH and Bs ICDH, the residues of 35\% are identical and those of $50 \%$ have similarity. The primary sequence alignment of Tth ICDH, Ec ICDH, and Bs ICDH is shown in Fig. 12. Enzymes from thermophiles are often highly homologous to the mesophilic counterparts and the catalytic mechanisms are usually identical. The thermophilic enzymes have to be stable enough to withstand denaturation at elevated temperature where the thermophile optimally grows and possess simultaneously the flexibility required for enzymatic activity. Comparison among these enzymes of functions and structural similarities suggest functional robustness. The crystal structure of Tth ICDH is shown in Fig. 13. The overall core structure resembles those of $E c$ ICDH and Bs ICDH. As shown in Fig. 14, it can be seen that the string of the extra residues constitutes clasp domain, and it appears playing a role in the formation of a stable dimer.

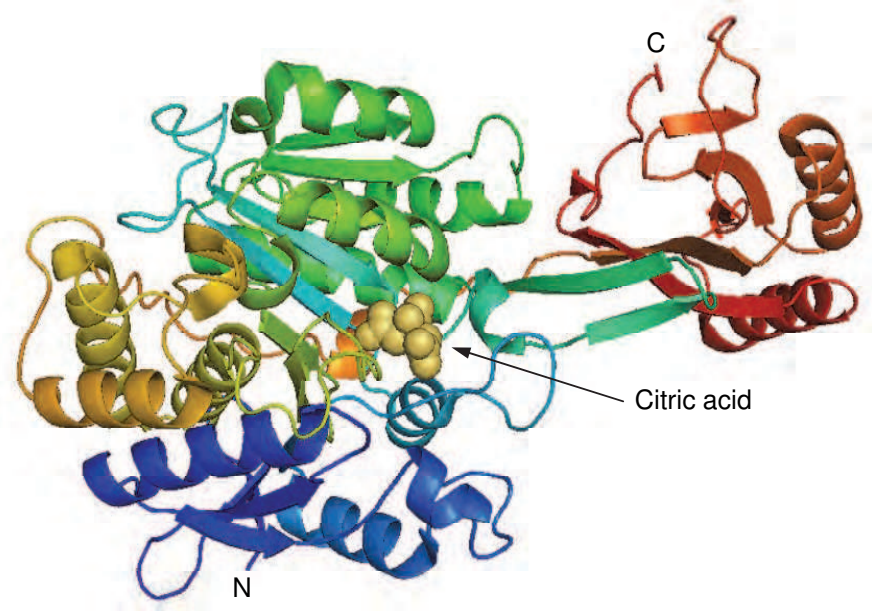

Fig. 13. C $\alpha$ trace of Tth ICDH monomer with citric acid. (PDB ID: 2D1C). Although there is a string of the extra sequence at the $C$ terminus region, overall folding manner is quit similar to $E c$ ICDH and Bs ICDH. It may the reflection of functional robustness of the protein.

Although the preliminary X-ray study and crystallization of Tth ICDH were already reported by Ohzeki et al. (1995), and quite recently the crystal structure was determined by Lakonath \& Kunishima (2006), we have described the other two curious crystal forms (crystal form I, and II) obtained for Tth ICDH under different crystallization conditions. Observation on the surface of one of the crystal forms (form II) by AFM motivated extended analysis on the possibility of Tth ICDH molecule taking the form of a supramolecular architecture under the condition and crystallization state. Study in this line leads to the important subject which concerns polymorphism of protein crystals, and has focused on the importance of spontaneous hierarchical construction with supramolecular assemblies as a block towards nano-composites. 


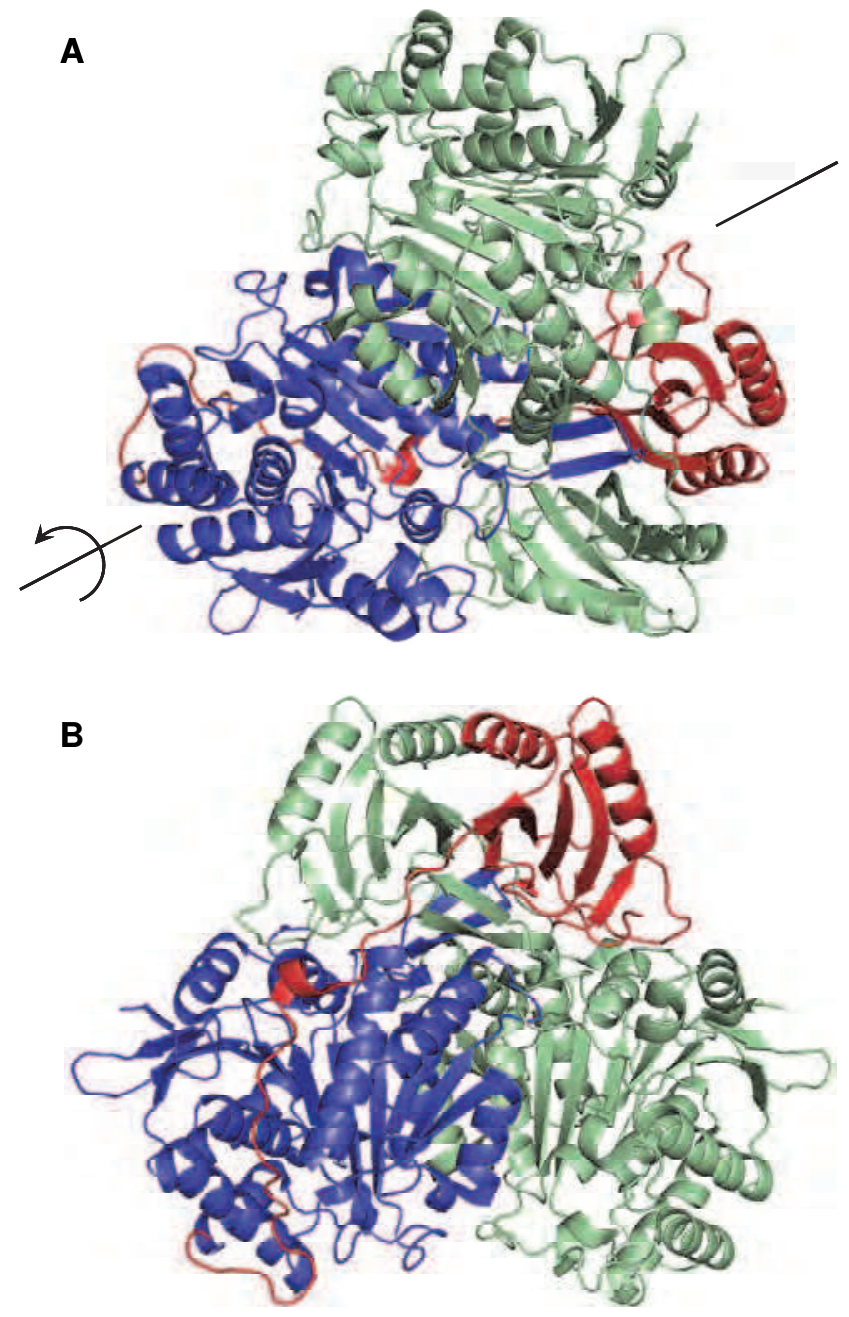

Fig. 14. Diagram of Tth ICDH dimer. (A) Monomer A is shown in blue with its 141 extra residues at the $C$ terminus region in red. Monomer $B$ is shown in pale-green. (B) in the view, Tth ICDH has been rotated $\sim 180^{\circ}$ around the axis indicated in (A). (PDB ID: 2D1C).

\section{Conclusion}

Although more than 40 structures including many mutants of homo-dimeric ICDH are available from Protein Data Bank (RCSB PDB), there are few structures with as clearly drawn electron density as the nicotinamide ribose moiety for example. It is understood that there lies the difficulty due to disorder, hence, further structural information is still requisite to elucidate the catalytic mechanism. Observation by AFM of the surface of the crystal form II of Tth ICDH suggested that the crystals consisted of huge ellipsoidal bodies of a homocomplex of ICDH, of which long axis' diameter was $18.6 \mathrm{~nm}$ and short one was $10.9 \mathrm{~nm}$. The 
HPLC gel filtration column chromatography of the protein co-existed with its form II crystals which had been incubated under the critical crystallization condition, thus supporting the line of the above assumption. The calculation using the preliminary X-ray diffraction data indicated that an asymmetric unit contains lots of oligomeric Tth ICDH in crystal form II. We have found huge supramolecular complex formation under the appropriate crystallization condition among the ICDH subfamilies, which concerns polymorphism of protein crystals.

\section{Acknowledgment}

The author thanks Dr. Kenneth S. Kim for discussion and critical reading the manuscript.

\section{References}

Akiba, T.; Ishii, N.; Rashid, N.; Morikawa, M.; Imanaka, T. \& Harata, K. (2005). Structure of RadB recombinase from a hyperthermophilic archaeon, Thermococcus kodakaraensis KOD1: an implication for the formation of a near-7-fold helical assembly. Nucleic Acids Res., Vol.33, No.10, (June 2005), pp. 3412-3423, ISSN 0305-1048

Audette, G.F.; Quail, J.W.; Hayakawa, K.; Bai, C.; Chen, R. \& Delbaere, L.T. (1999). Crystallization and preliminary $\mathrm{X}$-ray diffraction studies of monomeric isocitrate dehydrogenase from Corynebacterium glutamicum. Acta Crystallogr. D Biol. Crystallogr., Vol.55, No.9, (September 1999), pp. 1584-1585, ISSN 0907-4449

Biswas, S.; Kinbara, K.; Oya, N.; Ishii, N.; Taguchi, H. \& Aida, T. (2009). A tubular biocontainer: metal ion-induced 1D assembly of a molecularly engineered chaperonin. J. Am. Chem. Soc., Vol.131, No.22, (June 2009), pp. 7556-7557, ISSN 00027863

Ceccarelli, C.; Grodsky, N.B.; Ariyaratne, N.; Colman, R.F. \& Bahnson, B.J. (2002). Crystal structure of porcine mitochondrial $\mathrm{NADP}^{+}$-dependent isocitrate dehydrogenase complexed with $\mathrm{Mn}^{2+}$ and isocitrate. Insights into the enzyme mechanism. J. Biol. Chem., Vol.277, No.45, (November 2002), pp. 43454-43462, ISSN 0021-9258

Chen, R.D. \& Gadal, P. (1990). Structure, functions and regulation of NAD and NADP dependent isocitrate dehydrogenases in higher plants and in other organisms. Plant Physiol. Biochem., Vol.28, pp. 411-427, ISSN 0981-9428.

Collaborative Computing Project Number 4 (1994). The CCP4 suite: programs for protein crystallography. Acta Crystallogr. D, Vol.50, No.5, (September 1994), pp. 760-763, ISSN 0907-4449

Czerwinski, E.W.; Bethge, P.H.; Mathews, F.S. \& Chung, A.E. (1977). A preliminary crystallographic study of isocitrate dehydrogenase from Azotobacter vinelandii. J. Mol. Biol., Vol.116, No.1, (October 1977), pp. 181-187, ISSN 0022-2836

Doyle, S.A.; Beernink, P.T. \& Koshland Jr., D.E. (2001). Structural basis for a change in substrate specificity: Crystal structure of S113E isocitrate dehydrogenase in a complex with isopropylmalate, $\mathrm{Mg}^{2+}$, and NADP. Biochem., Vol.40, No.14, (March 2001), pp. 4234-4241, ISSN 0006-2960

Endrizzi, J.; Zhang, G.; Xiong, W.C.; Hurley, J.H.; Remington, S.J. \& Colman, R.F. (1996). Crystallization and preliminary diffraction analysis of porcine heart mitochondrial $\mathrm{NADP}^{+}$-dependent isocitrate dehydrogenase. Acta Crystallogr. D Biol. Crystallogr., Vol.52, No.5, (September 1996), pp. 1024-1026, ISSN 0907-4449 
Fedøy, A.E.; Yang, N.; Martinez, A.; Leiros, H.K. \& Steen, I.H. (2007). Structural and functional properties of isocitrate dehydrogenase from the psychrophilic bacterium Desulfotalea psychrophila reveal a cold-active enzyme with an unusual high thermal stability. J. Mol. Biol., Vol.372, No.1, (September 2007), pp. 130-149, ISSN 0022-2836

Fukunaga, N.S.; Sahara, I.T.; Ishii, S.A. \& Suzuki, M. (1992). Purification and characterization of monomeric isocitrate dehydrogenase with NADP+-specificity from Vibrio parahaemolyticus Y-4. J. Biochem., Vol.112, No.6, (December 1992), pp. 849-855 ISSN 0021-924X

Hu, G.; Taylor, A.B.; McAlister-Henn, L. \& Hart, P.J. (2005). Crystallization and preliminary X-ray crystallographic analysis of yeast $\mathrm{NAD}^{+}$-specific isocitrate dehydrogenase. Acta Crystallogr. F Struct. Biol. Cryst. Commun., Vol.61, No.5, (May 2005), pp. 486488, ISSN 1744-3091

Hurley, J.H. \& Dean, A.M. (1994). Structure of 3-isopropylmalate dehydrogenase in complex with $\mathrm{NAD}^{+}$: ligand-induced loop closing and mechanism for cofactor specificity. Structure, Vol.2, No.11, (November 1994), pp. 1007-1016, ISSN 0969-2126

Hurley, J.H.; Dean, A.M.; Sohl, J.L. \& Koshland Jr, D.E. (1990). Regulation of an enzyme by phosphorylation at the active site. Science, Vol.249, No. 4972, (August 1990), pp. 1012-1016, ISSN 0036-8075

Hurley, J.H.; Thorsness, P.E.; Ramalingam, V.; Helmers, N.H. Koshland Jr, D.E. \& Stroud, R.M. (1989). Structure of a bacterial enzyme regulated by phosphorylation, isocitrate dehydrogenase. Proc. Natl. Acad. Sci. USA, Vol.86, No.22, (November 1989), pp.8635-8639, ISSN 0027-8424

Imabayashi, F.; Aich, S.; Prasad, L. \& Delbaere, L.T. (2006). Substrate-free structure of a monomeric NADP isocitrate dehydrogenase: an open conformation phylogenetic relationship of isocitrate dehydrogenase. Proteins, Vol.63, No.1, (April 2006), pp. 100-112, ISSN 0887-3585

Imada, K.; Tamura, T.; Takenaka, R.; Kobayashi, I.; Namba, K. \& Inagaki, K. (2008). Structure and quantum chemical analysis of $\mathrm{NAD}^{+-d e p e n d e n t ~ i s o c i t r a t e ~}$ dehydrogenase: hydride transfer and co-factor specificity. Proteins, Vol.70, No.1, (January 2008), pp. 63-71, ISSN 0887-3585

Ishii, D.; Kinbara, K.; Ishida, Y.; Ishii, N.; Okochi, M.; Yohda, M. \& Aida, T. (2003). Chaperonin-mediated stabilization and ATP-triggered release of semiconductor nanoparticles. Nature, Vol.423, No.6940, (June 2003), pp. 628-632, ISSN 0028-0836

Ishii, N.; Haga, K.; Yamane, K. \& Harata, K. (2000a). Crystal structure of asparagine 233replaced cyclodextrin glucanotransferase from alkalophilic Bacillus sp. 1011 determined at $1.9 \AA$ resolution. J. Mol. Recognit., Vol.13, No.1, (January-February 2000), pp. 35-43 ISSN 0952-3499

Ishii, N.; Haga, K.; Yamane, K. \& Harata, K. (2000b). Crystal structure of alkalophilic asparagine 233-replaced cyclodextrin glucanotransferase complexed with an inhibitor, acarbose, at 2.0 Å resolution. J. Biochem., Vol.127, No.3, (March 2000), pp. 383-391, ISSN 0021-924X

Ishii, N.; Saijo, S.; Sato, T; Tanaka, N. \& Harata K. (2001). Crystallization and preliminary Xray studies of $\mathrm{V}_{1}$-ATPase of Thermus thermophilus HB8 complexed with Mg-ADP. J. Struct. Biol., Vol.134, No.1, (April 2001), pp. 88-92, ISSN 1047-8477

Ishii, N.; Umemura, K. \& Miyazaki, K. (2008). Supramolecular complex formation and crystallization of isocitrate dehydrogenase from Thermus thermophilus HB8: 
Preliminary studies with X-ray crystallography and atomic force microscopy. Biosci. Biotechnol. Biochem., Vol.72, No.9, (September 2008), pp. 2369-2376, ISSN 0916-8451

Jeong, J.J.; Sonoda, T.; Fushinobu, S.; Shoun, H. \& Wakagi, T. (2004). Crystal structure of isocitrate dehydrogenase from Aeropyrum pernix. Proteins, Vol.55, No.4, (June 2004), pp. 1087-1089, ISSN 0887-3585

Karlström, M.; Steen, I.H.; Madern, D.; Fedöy, A.E.; Birkeland, N.K. \& Ladenstein, R. (2006). The crystal structure of a hyperthermostable subfamily II isocitrate dehydrogenase from Thermotoga maritima. FEBS J., Vol.273, No.13, (July 2006), pp. 2851-2868, ISSN $1742-464 X$

Karlström, M.; Steen, I.H.; Tibbelin, G.; Lien, T.; Birkeland, N.K. \& Ladenstein, R. (2002). Crystallization and preliminary $\mathrm{X}$-ray structure analysis of isocitrate dehydrogenase from two hyperthermophiles, Aeropyrum pernix and Thermotoga maritima. Acta Crystallogr. D Biol. Crystallogr., Vol.58, No.12, (November 2002), pp. 2162-2164, ISSN 0907-4449

Karlström, M.; Stokke, R.; Steen, I.H.; Birkeland, N.K. \& Ladenstein, R. (2005). Isocitrate dehydrogenase from the hyperthermophile Aeropyrum pernix: X-ray structure analysis of a ternary enzyme-substrate complex and thermal stability. J. Mol. Biol., Vol. 345, No.3, (January 2005), pp. 559-577, ISSN 0022-2836

Kunz, W.; Henle, J. \& Ninham, B.W. (2005). 'Zur Lehre von der Wirkung der Salze' (about the science of the effect of salts): Franz Hofmeister's historical papers. Curr. Opin. Coll. Interface Sci., Vol.9, No.1-2, (August 2004), pp. 19-37, ISSN 1359-0294

Laemmli, U.K. (1970). Cleavage of structural proteins during the assembly of the head of bacteriophage T4. Nature, Vol.227, No.5259, (August 1970), pp. 680-685, ISSN 00280836

Leslie, A.G.W. (1992). Joint CCP4 and ESF-EACMB Newsletter on Protein Crystallography No.26, Daresbury Laboratory, Warrington, UK., 1992

Leyland, M.L. \& Kelly, R. (1991). Purification and characterization of a monomeric isocitrate dehydrogenase with dual coenzyme specificity from the photosynthetic bacterium Rhodomicrobium vannielii. Eur. J. Biochem., Vol.202, No.1, (November 1991), pp. 8593, ISSN 1432-1033

Lokanath, N.K. \& Kunishima, N. (2006). Crystal structure of TT0538 protein from Thermus thermophilus HB8, In: RCSB PDB (Protain Data Bank), July 2011, Available from: < http:/ / www.rcsb.org/pdb/explore/explore.do?structureId=2D1C >

Malkin, A.J. \& Thorne, R.E. (2004). Growth and disorder of macromolecular crystals: insights from atomic force microscopy and X-ray diffraction studies. Methods, Vol.34, No.3, (November 2004), pp. 273-299, ISSN 1046-2023

Matthews, B.W. (1968). Solvent content of protein crystals. J. Mol. Biol., Vol.33, No.2, (April 1968), pp. 491-497, ISSN 0022-2836

McPherson, A. (2004). Introduction to protein crystallization. Methods, Vol.34, No.3, (November 2004), pp. 254-265, ISSN 1046-2023

Melendez-Hevia, E.; Waddell, T.G. \& Cascante, M. (1996). The puzzle of the Krebs citric acid cycle: assembling the pieces of chemically feasible reactions, and opportunism in the design of metabolic pathways during evolution. J. Mol. Evol., Vol.43, No.3, pp. 293-303, ISSN 0022-2844

Mesecar, A.D. \& Koshland Jr., D.E. (2000). A new model for protein stereospecificity. Nature, Vol.403, No.6770, (February 2000), pp. 614-615, ISSN 0028-0836 
Mesecar, A.D.; Stoddard, B.L. \& Koshland Jr., D.E. (1997). Orbital steering in the catalytic power of enzymes: Small structural changes with large catalytic consequences. Science, Vol.277, No.202, (July 1997), pp. 202-206, ISSN 0036-8075

Miyazaki, K.; Eguchi, H.; Yamagishi, A.; Wakagi, T. \& Oshima, T. (1992). Molecular cloning of the isocitrate dehydrogenase gene of an extreme thermophile, Thermus thermophilus HB8. Appl. Environ. Microbiol., Vol.58, No.1, (January 1992), pp. 93-98, ISSN 0099-2240

Miyazaki, K.; Yaoi, T. \& Oshima, T. (1994). Expression, purification, and substrate specificity of isocitrate dehydrogenase from Thermus thermophilus HB8. Eur. J. Biochem., Vol.221, No.3, (May 1994), pp. 899-903, ISSN 1432-1033

Ohzeki, M.; Yaoi, T.; Moriyama, H.; Oshima, T. \& Tanaka, N. (1995). Crystallization and preliminary X-ray studies of isocitrate dehydrogenase from Thermus thermophilus HB8. J. Biochem., Vol.118, No.4, (October 1995), pp. 679-680, ISSN 0021-924X

Sahara, T.; Takada, Y.; Takeuchi, Y.; Yamaoka, N. \& Fukunaga, N. (2002). Cloning, sequencing, and expression of a gene encoding the monomeric isocitrate dehydrogenase of the nitrogen-fixing bacterium, Azotobacter vinelandii. Biosci. Biotechnol. Biochem., Vol.66, No.3, (March 2002), pp. 489-500, ISSN 0916-8451

Scabert, F.A.; Henn, C. \& Engel, A. (1995). Native Escherichia coli OmpF porin surfaces probed by atomic force microscopy. Science, Vol.268, No.5207, (April 1995), pp.9294 ISSN 0036-8075

Shiba, H.; Kawasumi, T.; Igarashi, Y.; Kodama, T. \& Minoda, Y. (1985). The $\mathrm{CO}_{2}$ assimilation via the reductive tricarboxylic acid cycle in an obligately autotrophic, aerobic hydrogen-oxidizing bacterium, Hydrogenobacter thermophilus. Arch. Microbiol., Vol.141, No.3, (April 1985), pp. 198-203, ISSN 0302-8933

Shimamura, T.; Koike-Takeshita, A.; Yokoyama, K.; Masui, R.; Murai, N.; Yoshida, M.; Taguchi, H. \& Iwata, S. (2004). Crystal structure of the native chaperonin complex from Thermus thermophilus revealed unexpected asymmetry at the cis-cavity. Structure, Vol.12, No.8, (August 2004), pp. 1471-1480, ISSN 0969-2126

Singh, S.K.; Matsuno, K.; LaPorte, D.C. \& Banaszak, L.J. (2001). Crystal structure of Bacillus subtilis isocitrate dehydrogenase at $1.55 \AA$ A. J. Biol. Chem., Vol.276, No.28, (July 2001), pp. 26154-26163, ISSN 0021-9258

Steen, I.H.; Lien, T. \& Birkeland, N.K. (1997). Biochemical and phylogenetic characterization of isocitrate dehydrogenase from a hyperthermophilic archaeon, Archaeoglobus fulgidus. Arch. Microbiol., Vol.168, No.5, (November 1997), pp. 412-420, ISSN 03028933

Steen, I.H.; Madern, D.; Karlström, M.; Lien, T.; Ladenstein, R. \& Birkeland, N.K. (2001). Comparison of isocitrate dehydrogenase from three hyperthermophiles reveals differences in thermostability, cofactor specificity, oligomeric state, and phylogenetic affiliation. J. Biol. Chem., Vol.276, No.47, (August 2001), pp. 4392443931, ISSN 0021-9258

Stoddard, B.L.; Dean, A. \& Koshland Jr, D.E. (1993). Structure of isocitrate dehydrogenase with isocitrate, nicotinamide adenine dinucleotide phosphate, and calcium at $2.5-\AA$ resolution: a pseudo-Michaelis ternary complex. Biochem., Vol.32, No.36, (September 1993), pp. 9310-9316 ISSN 0006-2960

Stokke, R.; Karlström, M.; Yang, N.; Leiros, I.; Ladenstein, R.; Birkeland, N.K. \& Steen, I.H. (2007). Thermal stability of isocitrate dehydrogenase from Archaeoglobus fulgidus 
studied by crystal structure analysis and engineering of chimers. Extremophiles, Vol.11, No.3, (May 2007), pp. 481-493, ISSN 1431-0651

Xu, X.; Zhao, J.; Xu, Z.; Peng, B.; Huang, Q.; Arnold, E. \& Ding, J. (2004). Structures of human cytosolic NADP-dependent isocitrate dehydrogenase reveal a novel selfregulatory mechanism of activity. J. Biol. Chem., Vo.279, No.32, (August 2004), pp. 33946-33957, ISSN 0021-9258

Yasutake, Y.; Watanabe, S.; Yao, M.; Takada, Y.; Fukunaga, N. \& Tanaka, I. (2001). Crystallization and preliminary $\mathrm{X}$-ray diffraction studies of monomeric isocitrate dehydrogenase by the MAD method using Mn atoms. Acta Crystallogr. D Biol. Crystallogr., Vol.57, No.11, (November 2001), pp. 1682-1685 ISSN 0907-4449

Yoneta, M.; Sahara, T.; Nitta, K. \& Takada, Y. (2004). Characterization of chimeric isocitrate dehydrogenases of a mesophilic nitrogen-fixing bacterium, Azotobacter vinelandii, and a psychrophilic bacterium, Colwellia maris. Curr. Microbiol., Vol.48, No.5, (May 2004), pp. 383-388, ISSN 0343-8651 


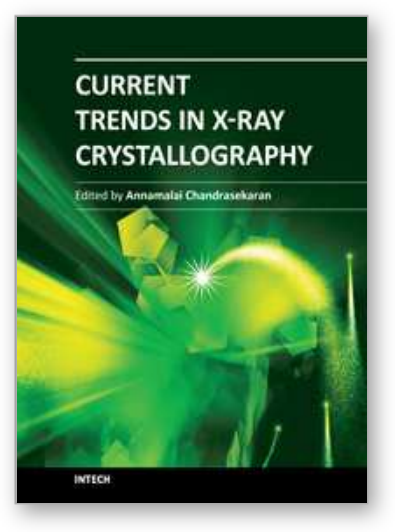

\author{
Current Trends in X-Ray Crystallography \\ Edited by Dr. Annamalai Chandrasekaran
}

ISBN 978-953-307-754-3

Hard cover, 436 pages

Publisher InTech

Published online 16, December, 2011

Published in print edition December, 2011

This book on X-ray Crystallography is a compilation of current trends in the use of X-ray crystallography and related structural determination methods in various fields. The methods covered here include single crystal small-molecule X-ray crystallography, macromolecular (protein) single crystal X-ray crystallography, and scattering and spectroscopic complimentary methods. The fields range from simple organic compounds, metal complexes to proteins, and also cover the meta-analyses of the database for weak interactions.

\title{
How to reference
}

In order to correctly reference this scholarly work, feel free to copy and paste the following:

Noriyuki Ishii (2011). Crystallization, Structure and Functional Robustness of Isocitrate Dehydrogenases, Current Trends in X-Ray Crystallography, Dr. Annamalai Chandrasekaran (Ed.), ISBN: 978-953-307-754-3, InTech, Available from: http://www.intechopen.com/books/current-trends-in-x-raycrystallography/crystallization-structure-and-functional-robustness-of-isocitrate-dehydrogenases

\section{INTECH}

open science | open minds

\section{InTech Europe}

University Campus STeP Ri

Slavka Krautzeka 83/A

51000 Rijeka, Croatia

Phone: +385 (51) 770447

Fax: +385 (51) 686166

www.intechopen.com

\section{InTech China}

Unit 405, Office Block, Hotel Equatorial Shanghai

No.65, Yan An Road (West), Shanghai, 200040, China

中国上海市延安西路65号上海国际贵都大饭店办公楼 405 单元

Phone: +86-21-62489820

Fax: +86-21-62489821 
(C) 2011 The Author(s). Licensee IntechOpen. This is an open access article distributed under the terms of the Creative Commons Attribution 3.0 License, which permits unrestricted use, distribution, and reproduction in any medium, provided the original work is properly cited. 